\title{
Enantioselective Rauhut-Currier-Type Cyclizations via Dienamine Activation: Scope and Mechanism
}

\author{
Eugenia Marqués-López, ${ }^{\text {a,b }}$ Raquel P. Herrera, ${ }^{\mathrm{a}, \mathrm{b}}$ Timo Marks, ${ }^{\mathrm{a}}$ Wiebke C. Jacobs, ${ }^{\mathrm{a}}$ Mathias Christmann*a \\ ${ }^{a}$ TU Dortmund University, Faculty of Chemistry, Otto-Hahn-Straße 6, 44227 Dortmund (Germany). \\ b Departamento de Química Orgánica. Instituto de Síntesis Química y Catálisis Homogénea (ISQCH), Universidad de Zaragoza-CSIC, \\ 50009 Zaragoza (Spain). ${ }^{1}$
}

Fax: (+49) 231-755-5363.

E-mails: mmaamarq@unizar.es, mathias.christmann@tu-dortmund.de

Received: The date will be inserted once the manuscript is accepted.

\begin{abstract}
:
This Feature Article describes our mechanistic studies in organocatalytic Rauhut-Currier-type reactions and some applications in target-oriented synthesis. The developed approach involves the cyclization of two tethered Michael acceptors via dienamine intermediates and leads to highly functionalized cycloalkenes. The utility of these intermediates is further demonstrated by the synthesis of biologically important targets, such as optically active iridoid derivatives.

1 Introduction

2 Organocatalytic Cyclization of Tethered $\alpha, \beta-$ Unsaturated Carbonyl Compounds - Synthesis of Cyclopentene Derivatives

2.1 Mechanistic Proposal

2.1.1 ESI-HRMS Measurements

2.1.2 NMR-Experiments

2.1.3 Complementary Reactivity

2.2 Synthetic Applications

3 Organocatalytic Cyclization of Tethered $\alpha, \beta$ Unsaturated Carbonyl Compounds - Synthesis of Cyclohexene Derivatives

4 Conclusions

Key words: asymmetric synthesis, organocatalysis, dienamine activation, Rauhut-Currier reaction, Michael addition, reaction mechanisms.
\end{abstract}

\section{Introduction}

The development of asymmetric transformations exerts considerable leverage on the efficiency of target-oriented syntheses. ${ }^{2}$ To this end, organocatalysis was shown to be a powerful alternative to metal-based and enzymatic catalysis., ${ }^{3,4}$ Within the field, aminocatalysis is probably the most explored area, thus, a great variety of primary and secondary chiral amines have been applied successfully to the synthesis of drugs and natural products. ${ }^{4 c, 5,6}$ In this respect, enamine $^{7}$ and iminium ion ${ }^{8}$ activation, have become an indispensable strategy in the enantioselective $\alpha{ }^{9}$ and $\beta-^{10}$ functionalization of carbonyl compounds. More recently, dienamine activation has gained attention for its synthetic potential. ${ }^{11,12}$ Nevertheless, only a small number of examples have appeared since the original work of Jørgensen and Hong, where the electrophilic reactivity of $\alpha, \beta$-unsaturated aldehydes is inverted by conversion into a nucleophilic species. ${ }^{13}$ Dienamine intermediates exhibit ambivalent reactivity
(Figure 1). Accordingly, they can be functionalized by suitable electrophiles in the $\alpha-{ }^{14}$ and $\gamma$-position. ${ }^{15,16} \mathrm{In}$ addition, dienamines can be employed as an electronrich diene in regular Diels-Alder-type reactions, ${ }^{17}$ as well as dienophiles in aza-Diels-Alder reactions with inverse electron demand. ${ }^{18,19}$

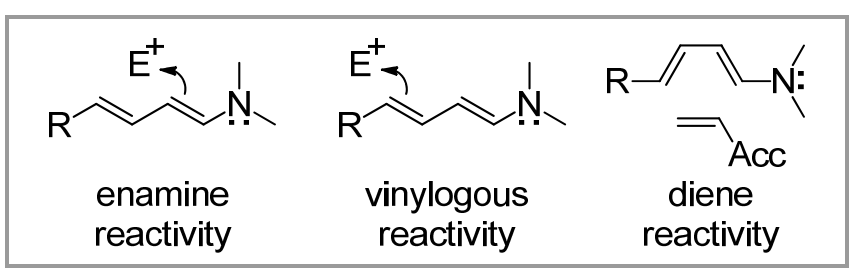

Figure 1 Dienamines as chemical chameleons.

The classical Rauhut-Currier (RC) reaction, also known as vinylogous Morita-Baylis-Hillman (MBH) reaction, involves the addition of an enolate generated in situ from a Michael acceptor (RC donor) to a second Michael acceptor (RC acceptor) (Scheme 1), while in the MBH reaction the acceptor is a carbonyl group. In the area of dienamine catalysis our group recently reported an $\alpha$-alkylation of $\alpha, \beta$-unsaturated aldehydes, affording Rauhut-Currier-type products in a mechanistically distinct reaction pathway. ${ }^{14 a}$

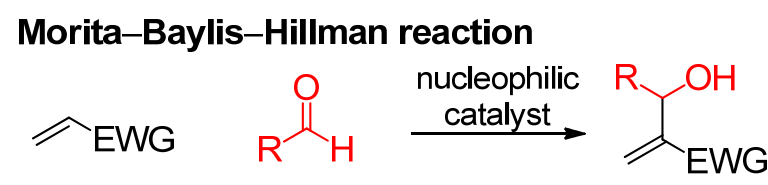

\section{Rauhut-Currier reaction}

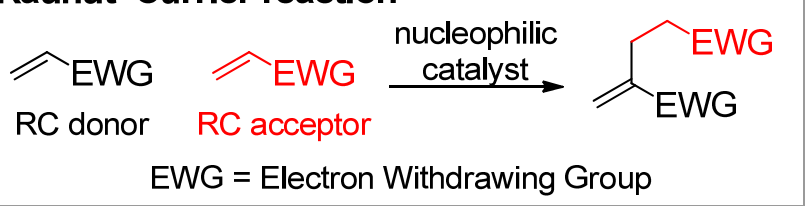

Scheme 1 General scheme for Morita-Baylis-Hillman (MBH) and Rauhut-Currier (RC) reactions.

Despite the obvious utility of the $\mathrm{RC}$ reaction for the formation of new $\mathrm{C}-\mathrm{C}$ bonds, only scarce examples of this reaction can be found in the years after its discovery in $1963{ }^{20,21}$ This is in contrast with the well-studied MBH reaction. ${ }^{22}$ However, the situation has changed in the last years, and an analysis of the 
recent literature indicates that the $\mathrm{RC}$ reaction is gathering increasing attention from several research groups.

A transannular version of the $\mathrm{RC}$ reaction was developed by Moore in 1999. ${ }^{23}$ Later Krische ${ }^{24}$ and Roush $^{25}$ investigated the intramolecular RC reaction using alkyl phosphines as nucleophilic catalysts. More recently, Miller, ${ }^{26} \mathrm{Wu},{ }^{27} \mathrm{Gu}$ and Xiao, ${ }^{28} \mathrm{Sasai}^{29}{ }^{29} \mathrm{Shi}^{30}$ and $\mathrm{Chi}^{31}$ have reported efficient enantioselective versions of the intramolecular $\mathrm{RC}$ reaction using nucleophilic organocatalysts (chiral phosphines or amines), bifunctional acid/base catalysis, or combinations of nucleophilic activation and hydrogen bonding catalysis. ${ }^{32,33}$ Further progress has been accomplished in the challenging intermolecular RC reaction via asymmetric organocatalysis. ${ }^{34,35}$

Highly functionalized cycloalkenes are important synthesis targets, as they are frequent substructure in biologically active molecules. ${ }^{36}$ Substituted cyclopentenes are frequently found in the iridoid class of natural products, ${ }^{37}$ which are widely distributed among plants and insects (Figure 2). ${ }^{38}$ In plants, iridoid glucosides are of particular interest as some of them exhibit pharmacological activity, while others are intermediates in the biosynthesis of alkaloids. ${ }^{39}$<smiles>CC1CCC(C=O)C1C=O</smiles>

iridodial<smiles>C=C(C=O)[C@H]1CCC(C)[C@H]1C=O</smiles>

anisomorphal<smiles>CC1=C(C=O)C(C)CCC1</smiles>
chrysomelidial<smiles>CC1=C(C=O)C(C=O)CC1</smiles>

rotundial<smiles>COC1=CCC2C(=O)OCC1C2C</smiles>

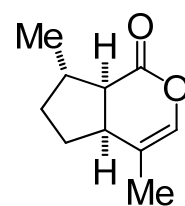

nepetalactone plagiolactone

Figure 2 Selected iridoids from insect defensive secretions.

There is evidence for the involvement of the RC reaction in the biosynthesis of natural products such as spinosyn A, a tetracyclic polyketide-derived insecticide from Saccharopolyspora spinosa. The enzyme SpnL was identified as responsible for the final cross-bridging step that completes the tetracyclic core of spinosyn A in a manner consistent with a Rauhut-Currier reaction. ${ }^{40} \mathrm{RC}$-type processes can be also invoked to explain the biosynthetic formation of some iridoid monoterpenes in insects, such as chrysomelidial (Scheme 2). ${ }^{41}$ A possible biosynthetic pathway suggests the formation of a dienamine intermediate that could be formed by condensation of an aldehyde function with an amino group of an enzyme. This intermediate could undergo an inverse electron-demand hetero Diels-Alder reaction providing the cis-fused plagiodial skeleton.
Hydrolysis and isomerization then leads to plagiodial and chrysomelidial, respectively.

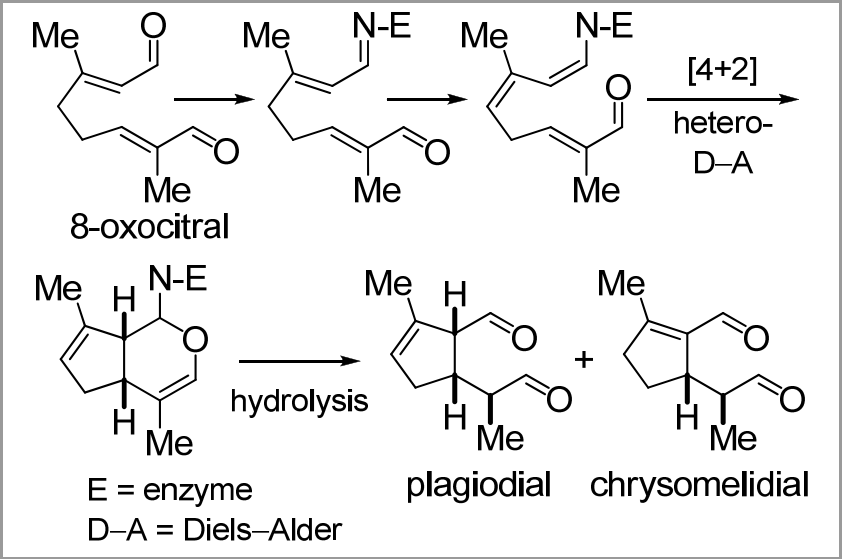

Scheme 2 Mechanistic hypothesis for the biosynthesis of plagiodial and chrysomelidial in insects.

Herein, we report our recent advances in the development of a mechanistically distinct Rauhut-Currier reaction using dienamine activation. ${ }^{14 a}$ Additional experiments confirm the important role of the $\beta$-methyl group on the substrates. Mechanistic studies also provided insight into the potential mechanism proposed for this reaction. The novelty, operational simplicity and the applicability to the synthesis of optically active iridoid derivatives as biologically relevant targets, renders this methodology a useful addition to conventional RC protocols.

As described in our previous communication, ${ }^{14 a}$ we began our investigation with the optimization of different reaction parameters such as catalyst, temperature, concentration, acid additive or solvent using ketoaldehyde 2a as model substrate for the cyclization (Scheme 3).

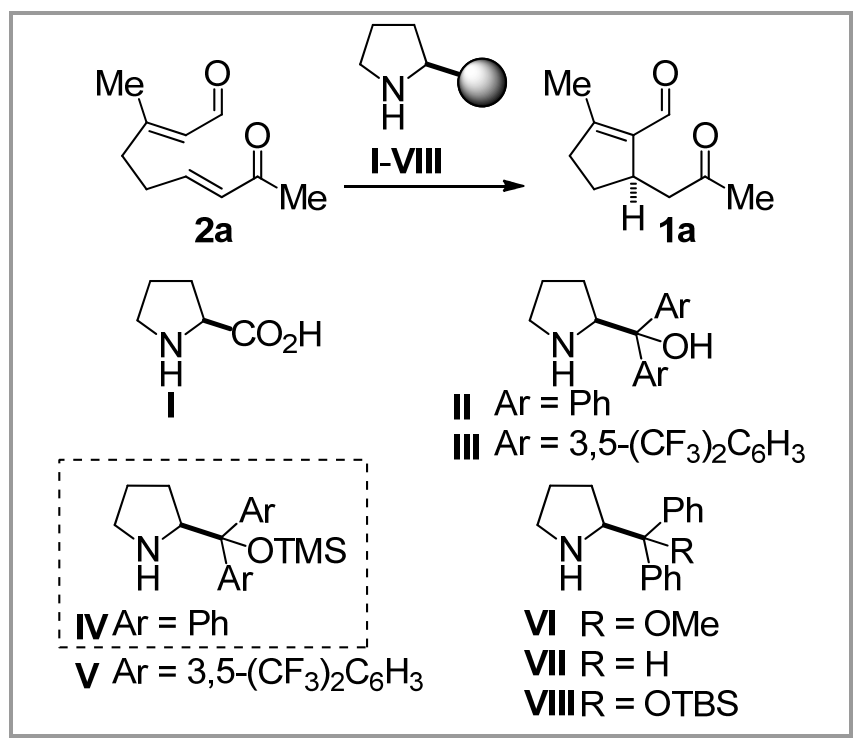

Scheme 3 Model reaction. 
In an initial screening of different chiral secondary amines as organocatalysts (I-VIII, Scheme 3), the steric bulk of the silyl and the aryl group were found to have a positive effect on the enantioselectivity of this process, however the use of very bulky catalysts resulted in poor reactivity. Thus, as a compromise between both reactivity and enantioselectivity, IV was identified as the most appropriate catalyst. We were also pleased to observe that the use of an acid additive such as acetic acid or benzoic acid, ${ }^{42}$ increased the reaction rate without affecting the enantioselectivity. After a study of different solvents and reaction temperatures, the best results were obtained in dichloromethane at room temperature. Other experiments, including the addition of $\mathrm{H}_{2} \mathrm{O}$, variation of the concentration, or slow addition of a solution of the starting material to the reaction mixture using a syringe pump, did not lead to any improvement. We then extended the method to several substrates and we also demonstrated its applicability carrying out an enantioselective synthesis of $(R)$-rotundial (Figure $2),{ }^{14 a}$ a potent natural mosquito repellent isolated from the plant Vitex rotundifolia. ${ }^{43}$ To the best of our knowledge this constituted the first organocatalytic enantioselective synthesis of $(R)$-rotundial in $25 \%$ overall yield, after 6 steps, and with good enantioselectivity $(86 \%$ ee $){ }^{44}$

\section{Organocatalytic Cyclization of Tethered $\alpha, \beta$ - Unsaturated Carbonyl Compounds - Synthesis of Cyclopentene Derivatives}

Furthermore, we investigated the scope of the cyclization under the optimized reaction conditions [IV $\cdot \mathrm{AcOH}(20 \mathrm{~mol} \%), \mathrm{CH}_{2} \mathrm{Cl}_{2}$, r.t.], furnishing the corresponding derivatives 1a-m in good yields and high enantioselectivities (Scheme 4), ${ }^{45}$ starting from an extended set of substrates $\mathbf{2 a - m}$ that was derived from double homologation of dialdehydes such as succinaldehyde or from commercially available sources such as geranyl acetate.

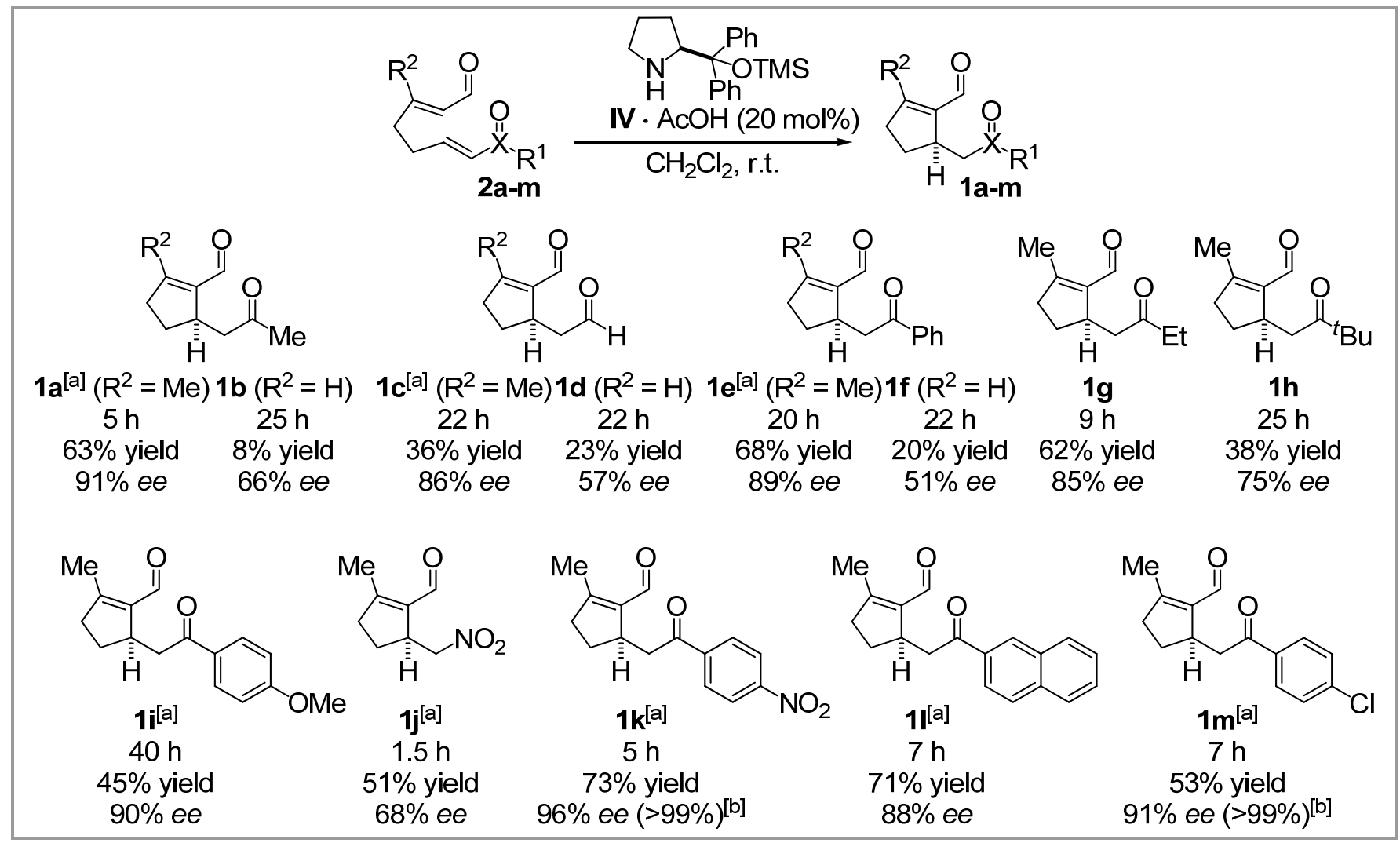

Scheme 4 Substrate scope. ${ }^{[a]}$ Results published in our previous communication. ${ }^{14 \mathrm{a}[\mathrm{b}]}$ After one recrystallization.

These results clearly demonstrate the flexibility of our methodology for introducing differently substituted carbonyl compounds such as aldehydes, aliphatic ketones, electron rich and electron poor aromatic ketones, and other groups such as nitroalkenes. We noted that the electronic properties at the $\mathrm{RC}$ acceptor strongly influence the reaction rate and the enantioselectivity of this process. Higher reaction rates can be achieved using Michael acceptors bearing substituents with electron-withdrawing groups (1k-m) whereas significantly lower reaction rates were observed with electron-donating substituents (1i). ${ }^{14 a}$ The use of $\alpha, \beta$-unsaturated alkyl ketones as RC acceptor affords the final adduct in high enantioselectivity with moderate to good yield (1a,g), unfortunately bulkier alkyl groups such as $t \mathrm{Bu}(\mathbf{1 h})$ lead to a lower yield but with good enantioselectivity. It was possible to employ another Michael acceptor 
such as nitroalkenes but the reaction proceeded with lower enantioselectivity (1j). ${ }^{14 a}$ In general, we have observed that prolonged reaction times led to reduced yields. In this respect, the formation of by-products is the major cause for that reduction, and may be attributed to the instability of aldehyde group.

Interestingly, when the substrate lacks a methyl group in the $\beta$-position of the RC donor aldehyde $(\mathbf{1 b}, \mathbf{d}, \mathbf{f})$, the results are inferior. Thus, the presence of this methyl group appears to be critical for the success of the process, in terms of both reactivity and enantioselectivity. Therefore and as previously suggested, the methyl group should play an important role in the mechanism of the reaction.

The absolute configuration of the product was determined to be $R$ by comparison of the optical rotation of rotundial (1c) with that reported in the literature, ${ }^{44}$ and further confirmed by X-ray analysis of compound $\mathbf{1 m} .^{14 \mathrm{a}}$ The $R$ configuration of the stereogenic center created by the dienamine catalysis was established and assumed for all products obtained (1a-m).

\subsection{Mechanistic Proposal}

In our previous report, we proposed the catalytic cycle shown in Scheme 5. ${ }^{14 a}$ The first step is the condensation of the substrate 2 with the catalyst IV. ${ }^{46}$ The resulting iminium ion $\mathbf{3}$ possibly exists in an equilibrium with the dienamines 4 and $4{ }^{, 13 b, 47}$ In this case, the reaction is completely $\alpha$-selective, probably due to steric reasons. The dienamine reacts as an enamine adding to the RC acceptor in an intramolecular Michael reaction leading to intermediate 5. It is worth mentioning that a mechanism proceeding through a [4+2]-cycloaddition of a dienamine intermediate was proposed by Boland for the biosynthesis of chrysomelidial and plagiodial as depicted in Scheme $2,^{41}$ and can be not ruled out completely in this case, although the corresponding bicyclic intermediate 9 has not been detected in our process (Scheme 5). Traces of compound $\mathbf{8}$ resulting from the hydrolysis of intermediate 5 , have been observed by ${ }^{1} \mathrm{H}$ NMR. ${ }^{48}$ It should be noted that each step in the catalytic cycle is reversible and proton abstraction $(\mathbf{5} \rightarrow \mathbf{6})$ and reprotonation $(\mathbf{6} \rightarrow \mathbf{5})$ could easily lead to trans-5. Presumably, hydrolysis of $\mathbf{5}$ to $\mathbf{8}$ is slow; therefore, protonation of $\mathbf{6}$ in the $\gamma$-position leads to iminium ion 7 , and final hydrolysis releases the product $\mathbf{1}$ and regenerates the catalyst IV.

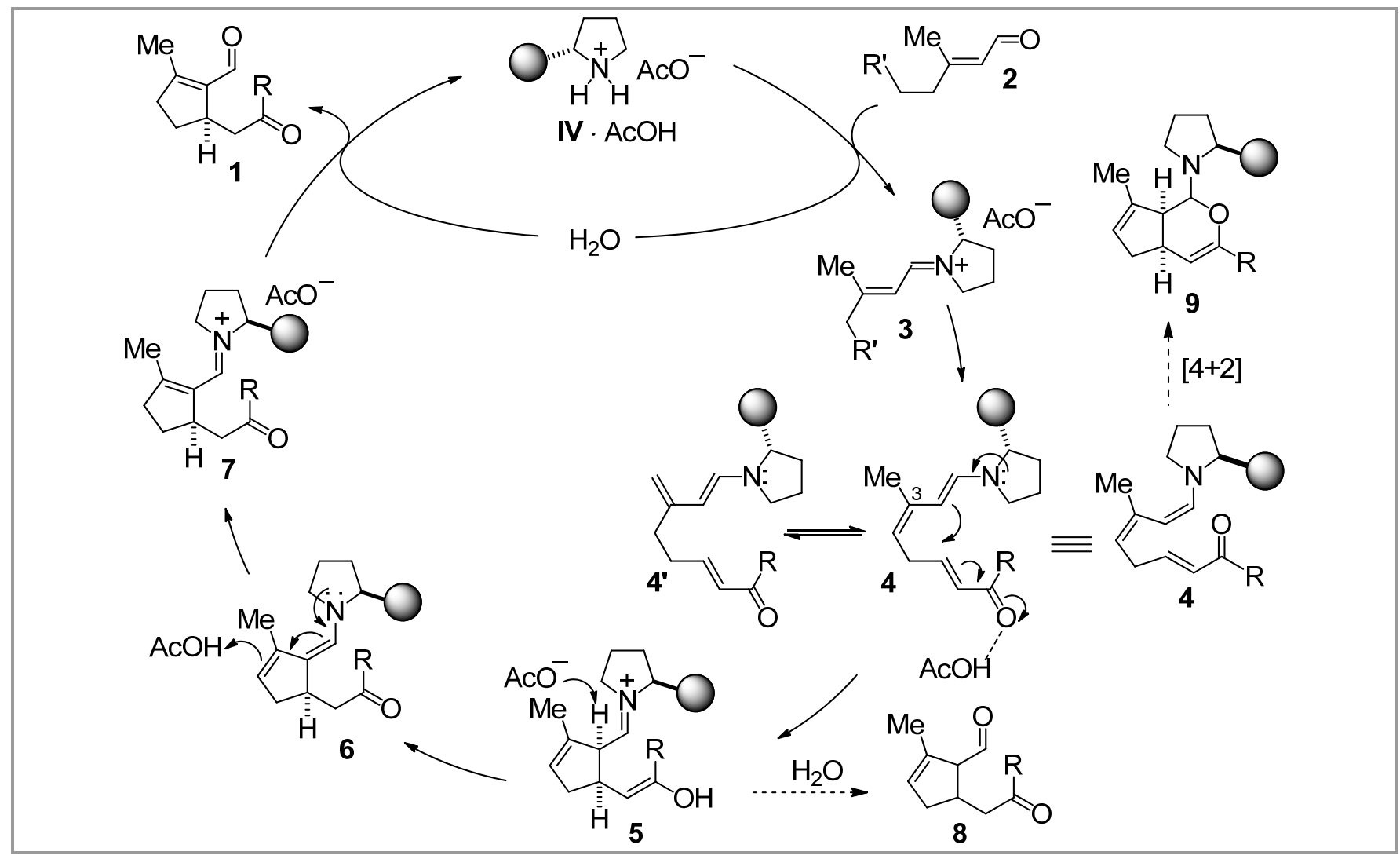

Scheme 5 Mechanistic hypothesis.

Based on our mechanistic proposal, we hypothesized that the $\beta$-methyl substituent in intermediate 4 could lower the relative energy of the required $3 Z$-configu- ration and its $E$-isomer for the following cyclization step (Scheme 5). In contrast, competitive side reactions, at the $\gamma$-position, could take place in 
absence of the methyl group, explaining the poor yield obtained for these substrates (2b,d,f). Moreover, the more favorable $3 E$-dienamine configuration cannot engage in the cyclization step.

In order to show that the double bond configuration in the enal starting material $\mathbf{2}$ is inconsequential for the selectivity of the reaction, an experiment with compound 2Z-2a was performed (Scheme 6). In this case, the same absolute configuration of compound 1a was obtained as the major one, with a similar yield in comparison with the experiment carried out with $E$ isomer ( $3 \mathrm{~h}, 53 \%$, 94\% ee vs $5 \mathrm{~h}, 63 \%, 91 \%$ ee). This observation could be explained if we assume that the $2 Z$-isomer and the $2 E$-isomer converge into the same dienamine 4 (Scheme 5).

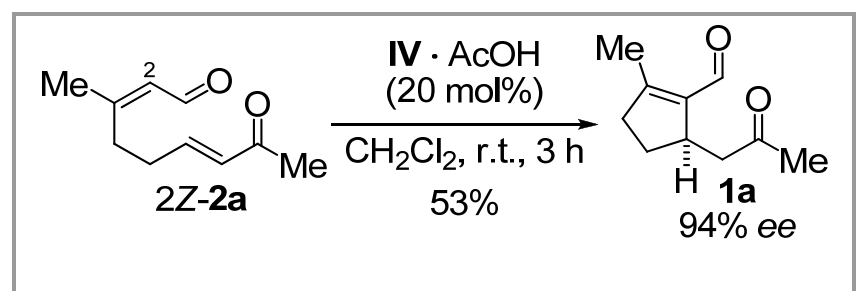

Scheme 6 Studying the influence of the double bond configuration of the enal starting material.

In order to support our mechanistic model and some of the proposed intermediates, we carried out HRMS and deuterium labeling experiments.

\subsubsection{ESI-HRMS Measurements}

We performed ESI-HRMS measurements using mixtures of aldehyde $\mathbf{2 m}$ and catalyst $\mathbf{I V}$ in order to find evidence for intermediates where the catalyst is covalently bound to the substrate. ${ }^{49}$ We could identify some mass peaks corresponding to different species involved in the mechanistic proposal in Scheme 5, such as the starting material $2 \mathrm{~m}(\mathrm{~m} / \mathrm{z} 263)$, the final product $1 \mathrm{~m}(\mathrm{~m} / \mathrm{z} 263)$, and the catalyst IV $(\mathrm{m} / \mathrm{z} 326)$, as well as other intermediates in the catalytic cycle, all with the same mass, for example $\mathbf{4 m}$ and $4 ' \mathrm{~m}(\mathrm{~m} / \mathrm{z}$ 570) (Figure 3). We were not able to detect intermediate $\mathbf{1 0}$ corresponding to the double condensation of the catalyst with both carbonyl groups. ${ }^{50}$ This fact was expected due to the low tendency for catalyst IV to activate the hindered ketone moiety. ${ }^{3}$ However, absence of evidence is not evidence of absence and thus the existence of such a possibly short-lived intermediate cannot be ruled out. Interestingly, the mass of the corresponding oxazolidine 11 (hemiaminal between substrate $\mathbf{2 m}$ and catalyst IV) was found ( $\mathrm{m} / \mathrm{z} 498)$, which is formed in situ after cleavage of the TMS group of the catalyst IV to give the free alcohol 12, detected also by HRMS $(\mathrm{m} / \mathrm{z} 254)$ (Figure 4). This would explain the relatively high catalyst loading required $(20 \mathrm{~mol} \%)$, for this process. The measured and calculated high resolution masses of the species are given in Table 1. These results support the reactive species given in our mechanistic hypothesis.

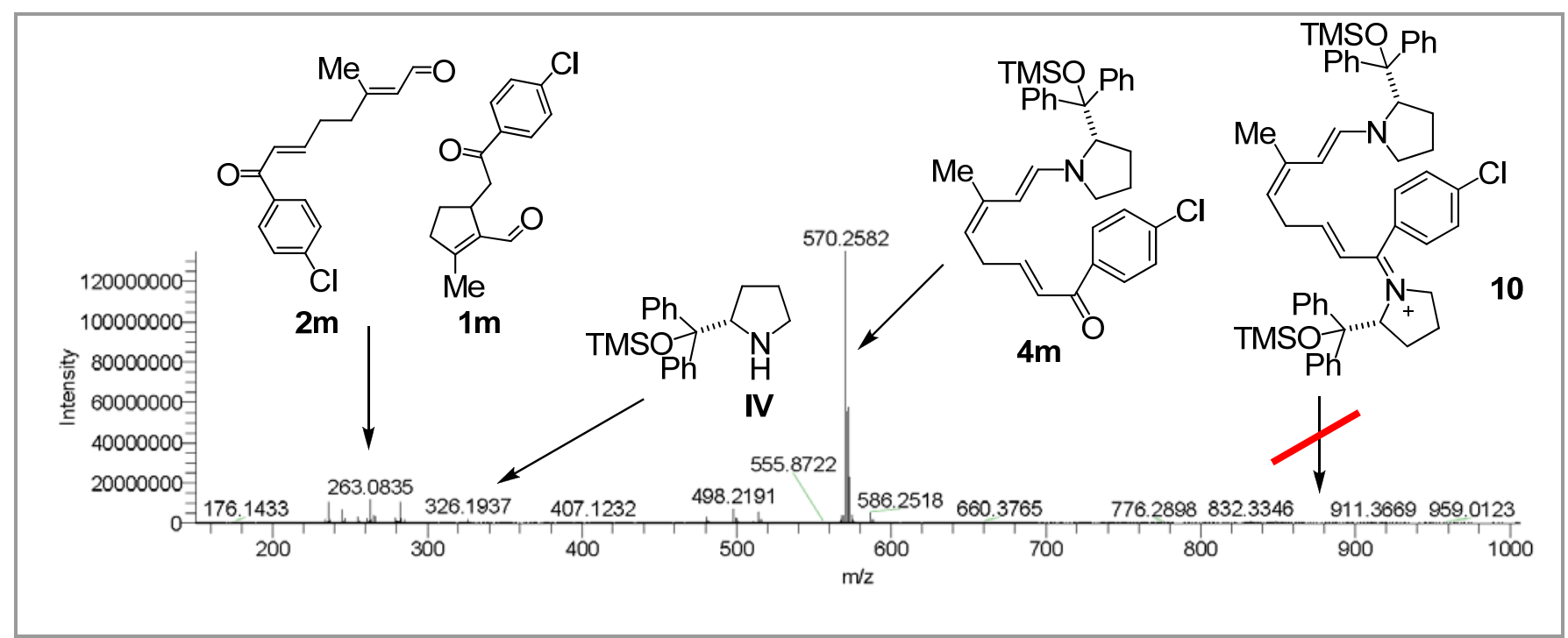

Figure 3 ESI-HRMS spectrum of the crude reaction mixture after five minutes. 


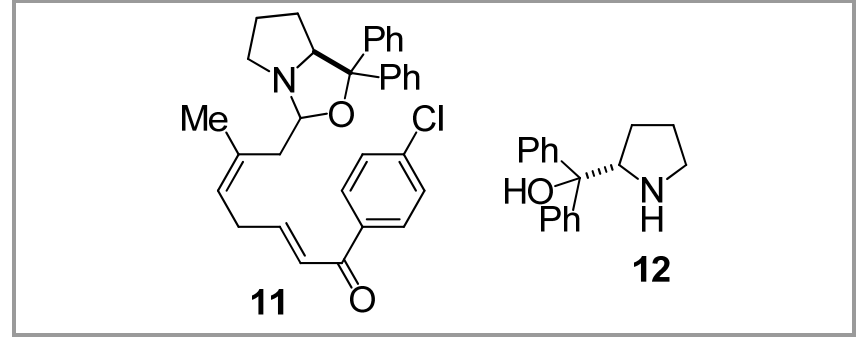

Figure 4 Oxazolidine 11 and alcohol free catalyst 12.

\begin{tabular}{lllll} 
Table 1 & \multicolumn{4}{c}{ HRMS (ESI) analysis of the detected intermediates. } \\
\hline Species & $\begin{array}{l}\text { Mass } \\
\text { (calcd) }\end{array}$ & $\begin{array}{l}\text { Mass } \\
\text { (found) }\end{array}$ & Formula & $\begin{array}{l}\text { Error } \\
\text { (ppm) }\end{array}$ \\
{$\left[\begin{array}{l}\mathbf{m}+\mathrm{H}]^{+} \\
{[\mathbf{1 m}+\mathrm{H}]^{+}}\end{array}\right.$} & 263.08333 & 263.08351 & $\mathrm{C}_{15} \mathrm{H}_{16} \mathrm{O}_{2} \mathrm{Cl}$ & 0.68311 \\
{$[\mathbf{I V}+\mathrm{H}]^{+}$} & 326.19347 & 326.19369 & $\mathrm{C}_{20} \mathrm{H}_{28} \mathrm{ONSi}$ & 0.66807 \\
{$[\mathbf{4 m}+\mathrm{H}]^{+}$} & 570.25896 & 570.25824 & $\mathrm{C}_{35} \mathrm{H}_{41} \mathrm{O}_{2} \mathrm{NClSi}$ & -1.26884 \\
{$[\mathbf{1 1}+\mathrm{H}]^{+}$} & 498.21943 & 498.21906 & $\mathrm{C}_{32} \mathrm{H}_{33} \mathrm{O}_{2} \mathrm{NCl}$ & -0.75845 \\
{$[\mathbf{1 2}+\mathrm{H}]^{+}$} & 254.15394 & 254.15424 & $\mathrm{C}_{17} \mathrm{H}_{20} \mathrm{ON}$ & 1.16840
\end{tabular}

\subsubsection{NMR Experiments}

In order to gain further evidence for the intermediacy of the dienamines $\mathbf{4}$ and $\mathbf{4}$ ', we performed an NMR experiment, examining the incorporation of deuterium into the final adduct 1l. First, the cyclization experiment of 2l was performed using deuterated solvent $\left(\mathrm{CD}_{2} \mathrm{Cl}_{2}\right)$ and acid (AcOD), and 1 equiv. of $\mathrm{D}_{2} \mathrm{O}$ (Scheme 7). Then, incorporation of deuterium was observed at positions $(\mathrm{a}-\mathrm{c})$ into the final product $1 \mathrm{l}$ by ${ }^{2} \mathrm{H} \mathrm{NMR}\left(\mathrm{CHCl}_{3}, 500 \mathrm{MHz}\right)$, as illustrated in Figure 5.

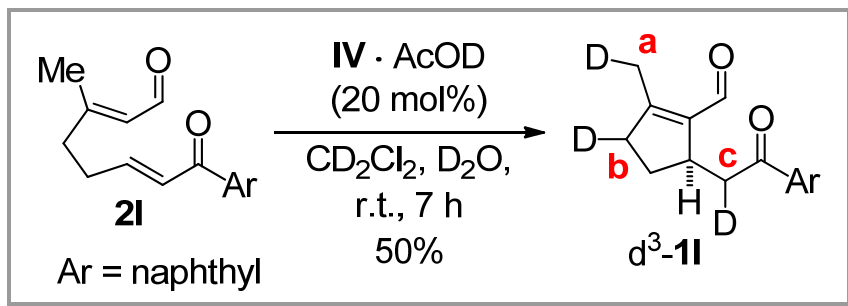

Scheme 7 Cyclization of $2 \mathbf{l}$ in $\mathrm{CD}_{2} \mathrm{Cl}_{2}$ and the presence of $\mathrm{D}_{2} \mathrm{O}$ and AcOD.

In the ${ }^{2} \mathrm{H}$ NMR spectrum, we could observe the incorporation of deuterium in the positions $\mathbf{a}$ and $\mathbf{b}$ which is in agreement with the formation of the two dienamines $\mathbf{4}$ and 4' as proposed in our mechanistic hypothesis. The observed deuterium incorporation in position $\mathbf{c}$ is a consequence of the deuteration of the enol 5 to give ketone $\mathbf{6}$ or a subsequent tautomerization (Scheme 5).

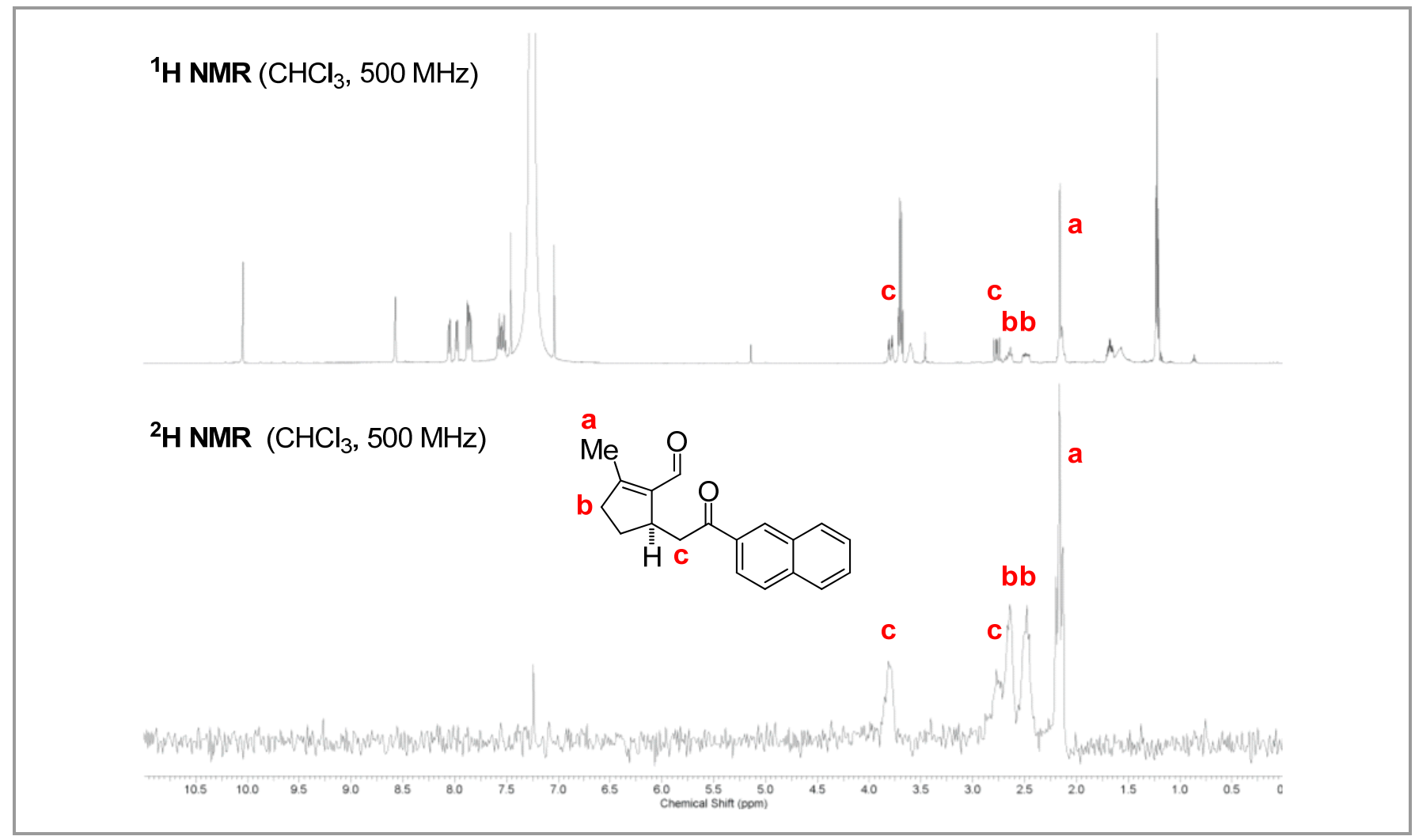

Figure $5{ }^{1} \mathrm{H}$ and ${ }^{2} \mathrm{H}$ NMR spectra of compound $\mathrm{d}^{3}-\mathbf{1 l}$. 


\subsubsection{Complementary Reactivity}

It is interesting to compare the reactivity profile of our RC-type reaction with classical $\mathrm{RC}$ reactions using nucleophilic phosphines, as previously described by Krische and Roush in 2002 (Scheme 8). ${ }^{24,25}$

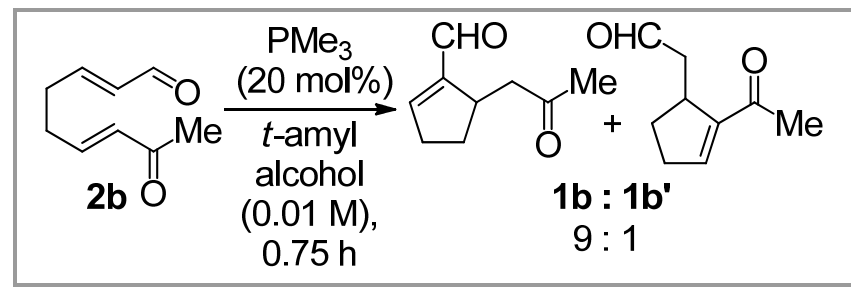

Scheme 8 Rauhut-Currier reaction catalyzed by $\mathrm{PMe}_{3}$.

When we applied our optimized conditions to substrate 2a (route a, Scheme 9), we only observed the formation of compound 1a in good yield and enantioselectivity. However, with the conditions of Roush (route b, Scheme 9), a complex mixture of products was obtained. While compound 1a was isolated in only $3 \%$ yield, instead 1a' $(6 \%)$ was the major product, that was prone to the formation of bicyclic follow-up products $11(8 \%)$ and $12(8 \%)$.

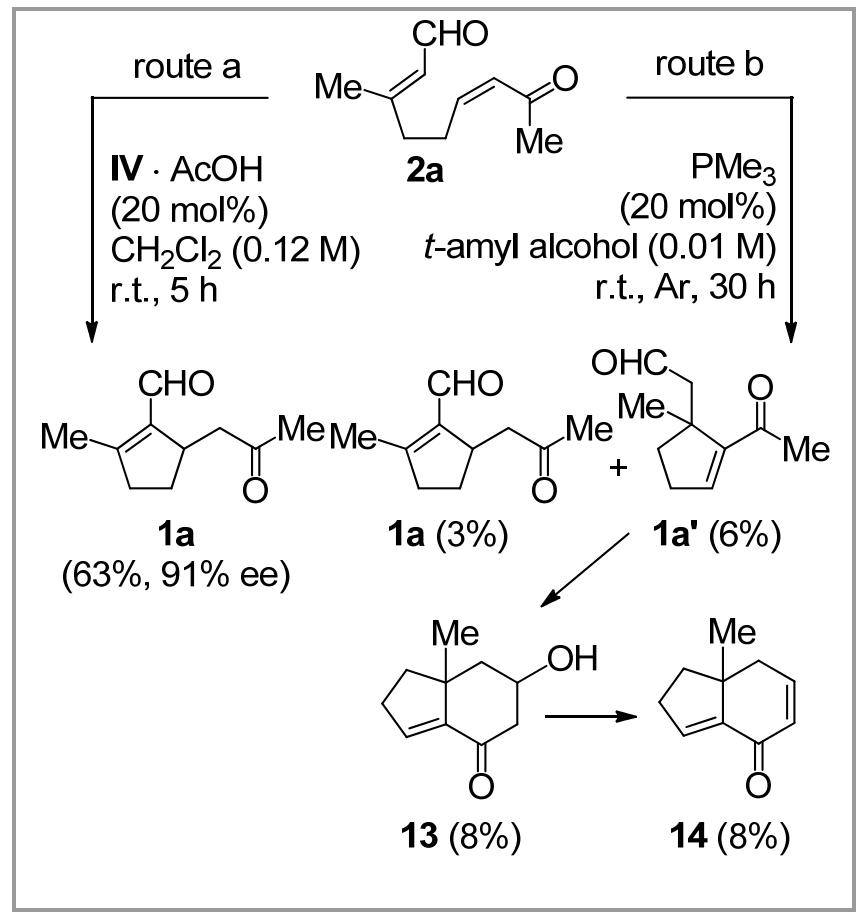

Scheme 9 Aminocatalysis $v s \mathrm{PMe}_{3}$ as organocatalyst in the cyclization of compound 2a.

This behavior can be explained with the classical RC activation, which is initiated by a 1,4-addition of the phosphine catalyst (Scheme 10). Due to steric and electronic effects, the $\beta$-substituted aldehyde appears to be less electrophilic than the unsubstituted $\alpha, \beta$ unsaturated ketone. In this sense the presence of the methyl group in the structure would direct the initial attack in each case affording complementary chemoselectivity. The mechanism explaining the formation of product 1a' is depicted in Scheme 10 and is in agreement with the expected Rauhut-Currier mechanism using phosphines as catalysts. The products 13 and 14 are believed to result from an intramolecular aldol addition/elimination.

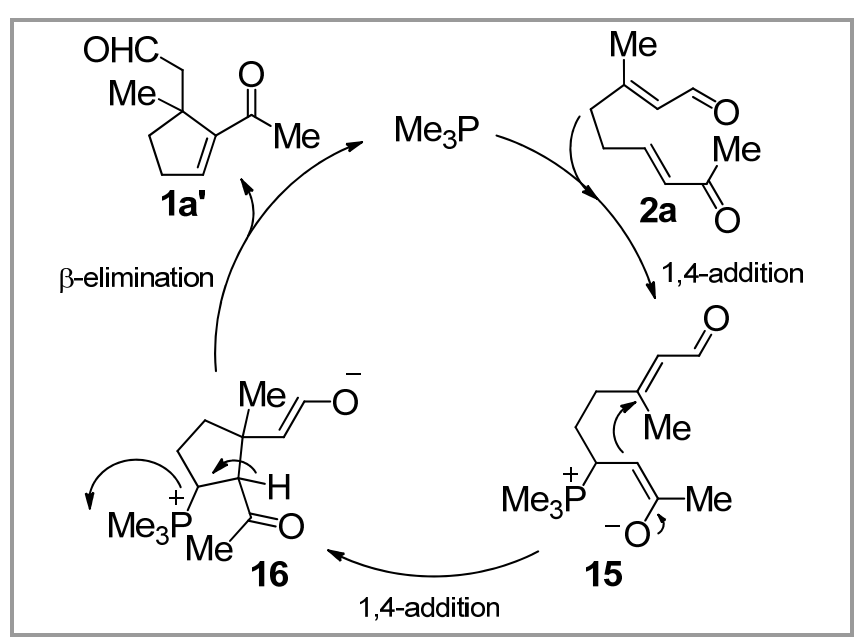

Scheme 10 Proposed mechanism for the formation of 1a'.

\subsection{Synthetic Applications}

In order to showcase the synthetic utility of this strategy, we embarked on the synthesis of the iridoid, mitsugashiwalactone (17), as we did previously using this method for the synthesis of rotundial (1c). ${ }^{14 a}$

The synthesis of (+)-mitsugashiwalactone $(\mathbf{1 7})^{51}$ was accomplished from dialdehyde 1d. After reduction to the diol 18, ${ }^{52}$ and oxidation to lactone 19 , the final product was obtained by a 1,4-addition of methyl cuprate (Scheme 11). ${ }^{53}$ Unfortunately, the product could not be obtained with high enantiomeric excess. It should be noticed that enantioselectivity dropped to $10 \%$ ee (from $43 \%$ ee) in the oxidation step of $\mathbf{1 8}$ to give 19. The low enantioselectivity in the formation of the cyclic precursor 1d was limiting the overall enantiomeric excess to $57 \%$ ee (Scheme 4).

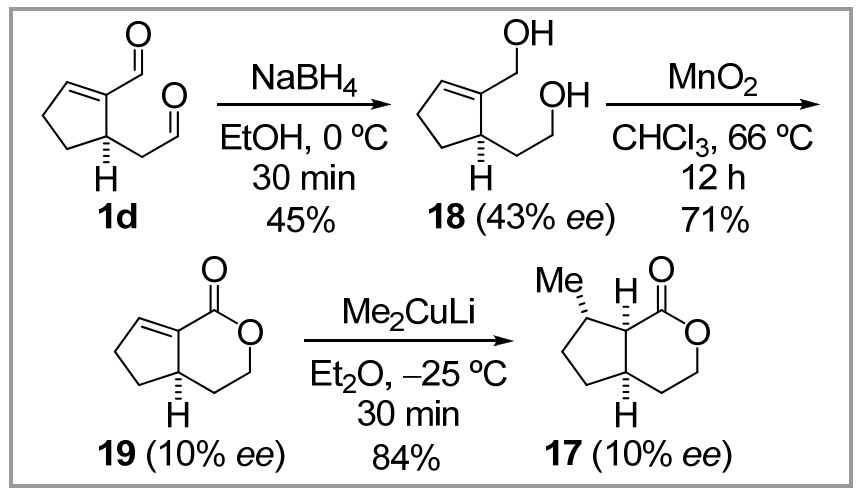

Scheme 11 Synthesis of (+)-mitsugashiwalactone (17). 


\section{Organocatalytic Cyclization of Tethered $\alpha, \beta$ - Unsaturated Carbonyl Compounds - Synthesis of Cyclohexene Derivatives}

We also studied the formation of six-membered rings, e.g. the trisubstituted cyclohexene derivatives 21a-b (Scheme 13). The synthesis of the required cyclization precursors (20a-b) is outlined in Scheme 12. Hydroxyaldehyde $\mathbf{2 4}$ was obtained from commercially available ketonitrile $\mathbf{2 2}$ by a HWE olefination followed by a Dibal-H reduction ${ }^{54}$ and subjected to a Wittig olefination with the respective phosphoranylidenes 25. After IBX oxidation of the allylic alcohols 26, ketoaldehydes 20a-b were obtained.

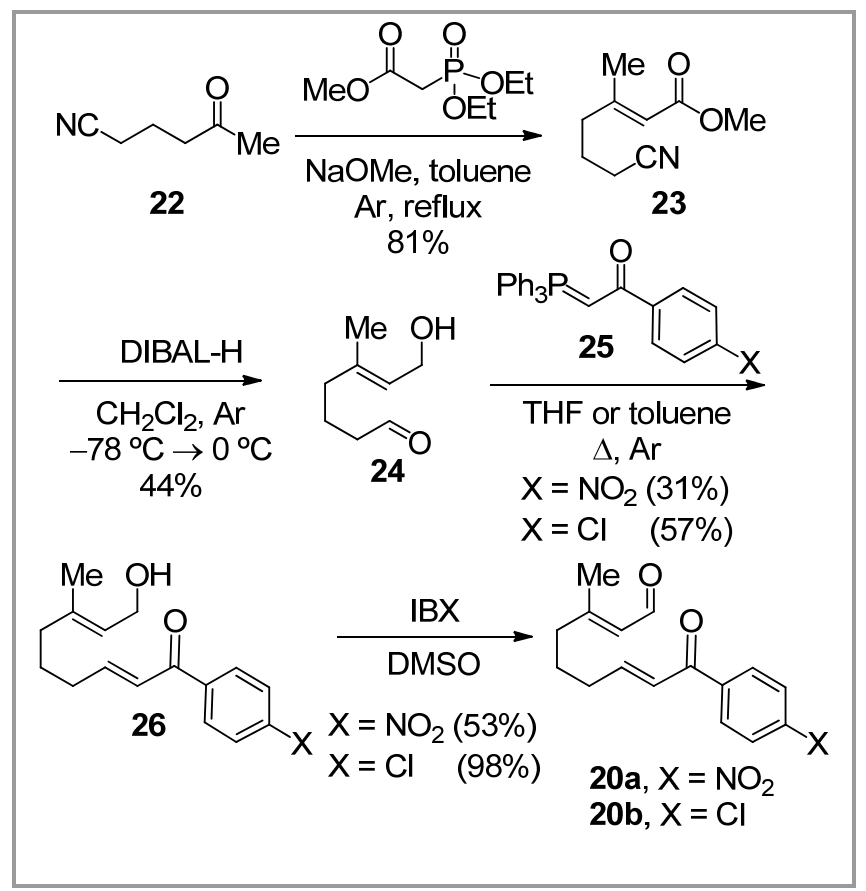

Scheme 12 Synthesis of the substrates 20a-b.

Unfortunately, when the substrates 20a-b were submitted to the conditions that were optimized for the formation of corresponding five-membered rings, only poor yields (7-9\%) were obtained albeit with good enantioselectivities (76-82\% ee) (Scheme 13). ${ }^{45}$

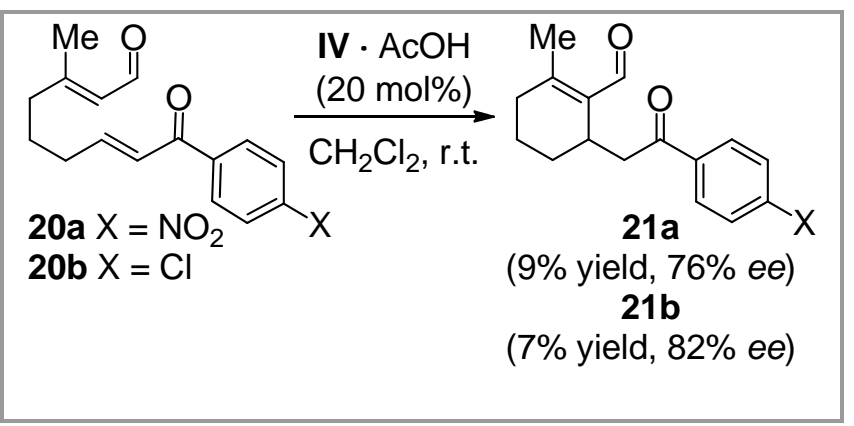

Scheme 13 Organocatalytic enantioselective cyclization of 20a-b.

The lower reaction rates observed in the cyclization reactions leading to 6-membered rings, as well as the poor yields, may be explained with competing decomposition of the starting material. Interestingly, in this instance we have been able to detect significant amounts of a non-conjugated cyclic product 27 from which we obtained single crystals (Figure 6). An Xray analysis revealed the relative configuration to be trans. ${ }^{55,56}$ This finding provides further support for the intermediacy of the elusive intermediates $\mathbf{5}$ and $\mathbf{8}$ from the cyclopentene series (Scheme 5).

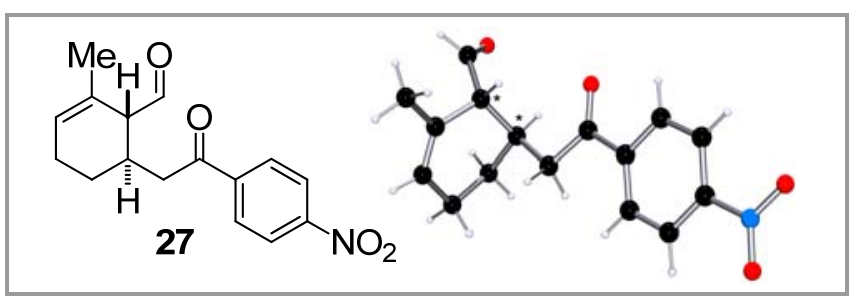

Figure 6 X-Ray structure of non-conjugated product 27.

\section{Conclusions}

In summary, we have provided new results and mechanistic studies for a better understanding of the enantioselective Rauhut-Currier-type reaction. We have investigated the cyclization of different substrates using dienamine activation affording cyclopentene derivatives in good yields and moderate to high enantioselectivities. The analysis of experiments such as ESI-HRMS or ${ }^{2} \mathrm{H}$ NMR, supports the proposed mechanism and reveals the importance of the methyl group in the $\beta$-carbon of the explored substrates. Our procedure represents a useful tool for the asymmetric synthesis of highly functionalized cyclopentenes, such as iridoid derivatives as biologically important targets. The formation of cyclohexene derivatives has been observed but leaves room for further optimization.

All commercially available solvents and reagents were used as received. Analytical thin layer chromatography was performed on Merck TLC silica gel $60 \mathrm{~F}_{254}$. Purification of reaction products was carried out by flash chromatography using silica gel (0.040-0.063 mm). NMR spectra were recorded on Bruker DPX300 (300 MHz), DRX400 (400 MHz) or DRX500 (500 MHz) spectrometers. Chemical shifts were reported in the $\delta$ scale relative to residual solvent peaks $\left[\mathrm{CHCl}_{3}: \delta 7.26 \mathrm{ppm}\left({ }^{1} \mathrm{H} \mathrm{NMR}\right)\right.$ and $77.16 \mathrm{ppm}$ $\left({ }^{13} \mathrm{C}\right.$ NMR $), \mathrm{CD}_{3} \mathrm{COCD}_{3}: \delta 2.05 \mathrm{ppm}\left({ }^{1} \mathrm{H} \mathrm{NMR}\right)$ and $206.26 \mathrm{ppm}\left({ }^{13} \mathrm{C}\right.$ NMR $)$ and $\mathrm{CD}_{3} \mathrm{OD}: \delta 3.31 \mathrm{ppm}$ $\left({ }^{1} \mathrm{H}\right.$ NMR $)$ and $49.00 \mathrm{ppm}\left({ }^{13} \mathrm{C}\right.$ NMR $\left.)\right]$. Chiral HPLC analysis was performed using an Agilent 1200 series HPLC with a diode array detector. Chiral columns include Daicel Chiralpak IA and IB. ${ }^{57}$

\section{Experimental Procedure for Cyclization of Compounds 2 and 20}

In a test tube, to a stirring solution of catalyst (S)-IV (20 mol\%) and acetic acid (20 mol\%) in $\mathrm{CH}_{2} \mathrm{Cl}_{2}$ $(1 \mathrm{~mL})$, a solution of $\mathbf{2}^{57}$ or $\mathbf{2 0}^{57}$ in $\mathrm{CH}_{2} \mathrm{Cl}_{2}(2 \mathrm{~mL})$ was 
added dropwise, and stirred at r.t. until consumption of the starting material (TLC). Then a saturated aqueous solution of $\mathrm{NaHCO}_{3}(2 \mathrm{~mL})$ was added and the aqueous phase was extracted with $\mathrm{CH}_{2} \mathrm{Cl}_{2}(2 \mathrm{x}$ $2 \mathrm{~mL})$ and $\mathrm{Et}_{2} \mathrm{O}(2 \times 2 \mathrm{~mL})$. The combined organic phases were dried over anhydrous $\mathrm{Na}_{2} \mathrm{SO}_{4}$ and the solvent was removed under reduced pressure after filtration. The crude product was purified by column chromatography on silica gel affording products 1 or $21{ }^{58}$ The reaction times, yields, and spectral and analytical data for $\mathbf{1}$ and $\mathbf{2 1}$ are as follows.

Organocatalytic Cyclization of 2 - Five Membered Rings

\section{(R)-5-(2-Oxopropyl)cyclopent-1-enecarbaldehyde}

(1b)

Following the general procedure starting from $\mathbf{2 b}$ $(54.79 \mathrm{mg}, 0.36 \mathrm{mmol})$, after $25 \mathrm{~h}$ of reaction, $\mathbf{1} \mathbf{b}^{25 \mathrm{a}}$ was obtained as yellow oil in $8 \%$ yield $(4.32 \mathrm{mg})$, after column chromatography $\left(\mathrm{SiO}_{2}\right.$, pentane/ $\mathrm{Et}_{2} \mathrm{O} 8: 1$ $\rightarrow 4: 1), 66 \%$ ee.

HPLC conditions: Daicel Chiralpak IA column (hexane/i-PrOH 95:5, flow rate $0.5 \mathrm{~mL} / \mathrm{min}$, UV 254.0 $\left.\mathrm{nm}, \tau_{\text {minor }}=17.4 \mathrm{~min} ; \tau_{\text {major }}=20.2 \mathrm{~min}\right)$.

$[\alpha]_{\mathrm{D}}^{24}+27.1\left(c=0.33, \mathrm{CHCl}_{3}, 66 \% e e\right)$.

\section{(R)-5-(2-Oxoethyl)cyclopent-1-enecarbaldehyde (1d)}

Following the general procedure starting from 2d $(55.00 \mathrm{mg}, 0.40 \mathrm{mmol})$, after $22 \mathrm{~h}$ of reaction, $1 \mathrm{~d}$ was obtained as colorless oil in $23 \%$ yield $(12.61 \mathrm{mg})$ after column chromatography $\left(\mathrm{SiO}_{2}\right.$, pentane $/ \mathrm{Et}_{2} \mathrm{O}$ 8:1 $\rightarrow$ $1: 1), 57 \%$ ee (after derivatization). ${ }^{57}$

IR $(\mathrm{KBr}$ film $)\left(\mathrm{cm}^{-1}\right)$ v 3020, 2926, 1722, 1677, 1493, 1453, 1216, 754, 669.

${ }^{1} \mathrm{H}$ NMR $\left(400 \mathrm{MHz}, \mathrm{CD}_{3} \mathrm{COCD}_{3}\right): \delta 9.77(\mathrm{~s}, 1 \mathrm{H})$, $9.74(\mathrm{t}, J=1.5 \mathrm{~Hz}, 1 \mathrm{H}), 7.06-7.04(\mathrm{~m}, 1 \mathrm{H}), 3.34(\mathrm{br} \mathrm{s}$, $1 \mathrm{H}), 2.86$ (ddd, $J=17.1,4.5,1.5 \mathrm{~Hz}, 1 \mathrm{H}), 2.70-2.50$ (m, 2H), 2.41 (ddd, $J=17.1,9.0,2.0 \mathrm{~Hz}, 1 \mathrm{H}), 2.34-$ $2.24(\mathrm{~m}, 1 \mathrm{H}), 1.70-1.62(\mathrm{~m}, 1 \mathrm{H})$.

${ }^{13} \mathrm{C}$ NMR $\left(100 \mathrm{MHz}, \mathrm{CD}_{3} \mathrm{COCD}_{3}\right): \delta 202.0,190.3$, 155.2, 149.6, 48.2, 37.4, 32.7, 31.0.

GC-EI-MS m/z (\%) 67 (92), 81 (75), 94 (100), 120 (50), $138(3)[\mathrm{M}]^{+}$.

GC-EI-HRMS ([M] $]^{+}$) calcd for $\mathrm{C}_{8} \mathrm{H}_{10} \mathrm{O}_{2}$ 138.0671, found 138.0675 .

\section{(R)-5-(2-Oxo-2-phenylethyl)cyclopent-1- enecarbaldehyde (1f)}

Following the general procedure starting from $2 \mathbf{2 f}$ $(77.13 \mathrm{mg}, 0.36 \mathrm{mmol})$, after $22 \mathrm{~h}$ of reaction, $\mathbf{1 f}$ was obtained as yellow oil in $20 \%$ yield $(15.43 \mathrm{mg}$ ) after column chromatography $\left(\mathrm{SiO}_{2}\right.$, pentane/ $\mathrm{Et}_{2} \mathrm{O}$ 8:1), $51 \%$ ee.

HPLC conditions: Daicel Chiralpak IA column (hexane $/ \mathrm{i}-\mathrm{PrOH}$ 90:10, flow rate $0.5 \mathrm{~mL} / \mathrm{min}$, UV $254.0 \mathrm{~nm}, \tau_{\text {minor }}=15.9 \mathrm{~min} ; \tau_{\text {major }}=17.8 \mathrm{~min}$ ).

$[\alpha]_{\mathrm{D}}^{24}+44.6\left(c=1.30, \mathrm{CHCl}_{3}, 51 \% e e\right)$.
IR (KBr film) $\left(\mathrm{cm}^{-1}\right) \vee 2937,2812,1677,1448,1363$, 1282, 1202, 984, 753, 692.

${ }^{1} \mathrm{H}$ NMR $\left(400 \mathrm{MHz}, \mathrm{CDCl}_{3}\right): \delta 9.81(\mathrm{~s}, 1 \mathrm{H}), 8.00-7.98$ $(\mathrm{m}, 2 \mathrm{H})$ 7.57-7.53 $(\mathrm{m}, 1 \mathrm{H}), 7.47-7.44(\mathrm{~m}, 2 \mathrm{H}), 6.94-$ $6.92(\mathrm{~m}, 1 \mathrm{H}), 3.72(\mathrm{dd}, J=16.5,3.0 \mathrm{~Hz}, 1 \mathrm{H}), 3.54(\mathrm{br}$ $\mathrm{s}, 1 \mathrm{H}), 2.75(\mathrm{dd}, J=16.5,10.5 \mathrm{~Hz}, 1 \mathrm{H}), 2.71-2.51(\mathrm{~m}$, $2 \mathrm{H}), 2.39-2.30(\mathrm{~m}, 1 \mathrm{H}), 1.77-1.69(\mathrm{~m}, 1 \mathrm{H})$.

${ }^{13} \mathrm{C}$ NMR (100 MHz, $\left.\mathrm{CDCl}_{3}\right): \delta 199.4,190.0,154.8$, $149.2,136.9,133.2,128.7,128.3,42.3,38.7,32.4$, 30.3 .

GC-EI-MS m/z (\%) 77 (40), 105 (100), 214 (8) [M] $]^{+}$.

HPLC-EI-HRMS ([M] $]^{+}$) calcd for $\mathrm{C}_{14} \mathrm{H}_{14} \mathrm{O}_{2} 214.0988$, found 214.0985 .

\section{(R)-2-Methyl-5-(2-(4-nitrophenyl)-2- oxoethyl)cyclopent-1-enecarbaldehyde (1g)}

Following the general procedure starting from $\mathbf{2 g}$ (130 mg, $0.72 \mathrm{mmol}$ ), after $9 \mathrm{~h}$ of reaction, $\mathbf{1 g}$ was obtained as yellow oil in $62 \%$ yield $(70.00 \mathrm{mg})$ after column chromatography $\left(\mathrm{SiO}_{2}\right.$, cyclohexane/EtOAc $3: 1), 85 \%$ ee.

HPLC conditions: Daicel Chiralpak IA column (hexane $/ \mathrm{i}$-PrOH $90: 10$, flow rate $0.5 \mathrm{~mL} / \mathrm{min}$, UV $254.4 \mathrm{~nm}, \tau_{\text {minor }}=17.0 \mathrm{~min} ; \tau_{\text {major }}=15.1 \mathrm{~min}$ ).

$[\alpha]_{\mathrm{D}}^{20}+109.7\left(c=1.0, \mathrm{CHCl}_{3}\right)$.

IR $(\mathrm{KBr})\left(\mathrm{cm}^{-1}\right) \vee 2975,2939,2834,2757,1712$, $1664,1631,1433,1411,1378,1350,1272,1190$, 1114, 1032, 977, 761, 584, 421.

${ }^{1} \mathrm{H}$ NMR $\left(400 \mathrm{MHz}, \mathrm{CDCl}_{3}\right): \delta 9.97(\mathrm{~s}, 1 \mathrm{H}), 3.41(\mathrm{br}$ $\mathrm{s}, 1 \mathrm{H}), 3.00(\mathrm{dd}, J=1.6,0.4 \mathrm{~Hz}, 1 \mathrm{H}), 2.63-2.55(\mathrm{~m}$, $1 \mathrm{H}), 2.51-2.32(\mathrm{~m}, 3 \mathrm{H}), 2.28(\mathrm{dd}, J=16.7,10.1 \mathrm{~Hz}$, $1 \mathrm{H}), 2.19-2.10(\mathrm{~m}, 1 \mathrm{H}), 2.13(\mathrm{~s}, 3 \mathrm{H}), 1.53-1.45(\mathrm{~m}$, $1 \mathrm{H}), 1.05(\mathrm{t}, J=0.8 \mathrm{~Hz}, 3 \mathrm{H})$.

${ }^{13} \mathrm{C} \mathrm{NMR}\left(400 \mathrm{MHz}, \mathrm{CDCl}_{3}\right): \delta 210.9,188.1,164.0$, $139.5,46.0,39.5,39.0,35.9,28.2,14.4,7.8$.

HPLC-ESI-HRMS $\left([\mathrm{M}+\mathrm{H}]^{+}\right)$calcd for $\mathrm{C}_{11} \mathrm{H}_{17} \mathrm{O}_{2}$ 181.25148, found 181.12223 .

(R)-2-Methyl-5-(2-(4-nitrophenyl)-2oxoethyl)cyclopent-1-enecarbaldehyde (1h)

Following the general procedure starting from $\mathbf{2 h}$ $(70.71 \mathrm{mg}, 0.34 \mathrm{mmol})$, after $25 \mathrm{~h}$ of reaction, $\mathbf{1 h}$ was obtained in $38 \%$ yield $(27 \mathrm{mg})$ after column chromatography $\left(\mathrm{SiO}_{2}\right.$, pentane/ $\mathrm{Et}_{2} \mathrm{O}$ 4:1), $75 \%$ ee.

HPLC conditions: Daicel Chiralpak IA column (hexane $/ \mathrm{i}-\mathrm{PrOH}$ 97:3, flow rate $0.5 \mathrm{~mL} / \mathrm{min}$, UV $254.4 \mathrm{~nm}, \tau_{\text {minor }}=13.4 \mathrm{~min} ; \tau_{\text {major }}=15.2 \mathrm{~min}$ ).

$[\alpha]_{\mathrm{D}}^{20}+92.7\left(c=1.03, \mathrm{CHCl}_{3}\right)$.

IR $(\mathrm{KBr})\left(\mathrm{cm}^{-1}\right) \vee 2968,1704,1662,1478,1394$, 3380, 1366, 1345, 1283, 1250, 1188, 1063, 1002.

${ }^{1} \mathrm{H}$ NMR $\left(400 \mathrm{MHz}, \mathrm{CDCl}_{3}\right): \delta 9.98(\mathrm{~s}, 1 \mathrm{H}), 3.41(\mathrm{br}$ $\mathrm{s}, 1 \mathrm{H}), 3.07(\mathrm{dd}, J=2.0,0.4 \mathrm{~Hz}, 1 \mathrm{H}), 2.62-2.53(\mathrm{~m}$, $1 \mathrm{H}), 2.50-2.37(\mathrm{~m}, 2 \mathrm{H}), 2.22-2.15(\mathrm{~m}, 1 \mathrm{H}), 2.14(\mathrm{~s}$, $3 \mathrm{H}), 1.42-1.34(\mathrm{~m}, 1 \mathrm{H}), 1.11$ (s, 9H).

${ }^{13} \mathrm{C}$ NMR $\left(400 \mathrm{MHz}, \mathrm{CDCl}_{3}\right): \delta 215.2,188.2,163.9$, 139.8, 44.0, 40.3, 39.4, 39.1, 28.4, 26.4 (3C), 14.5. 
HPLC-ESI-HRMS $\left([\mathrm{M}+\mathrm{H}]^{+}\right)$calcd for $\mathrm{C}_{13} \mathrm{H}_{21} \mathrm{O}_{2}$ 209.30464, found 209.15361.

\section{Cyclization of 2a Using $\mathrm{PMe}_{3}$ as Organocatalyst}

A solution of (2E,6Z)-3-methyl-8-oxonona-2,6-dienal (2a) $(59.83 \mathrm{mg}, 0.36 \mathrm{mmol})$ in tert-amyl alcohol (3.6 mL) was deoxygenated by bubbling Ar through the solution for $30 \mathrm{~min}$. To the oxygen-free solution was added $\mathrm{PMe}_{3}(7.8 \mu \mathrm{L}, 0.07 \mathrm{mmol})$ by $\mu$ syringe. ${ }^{25 \mathrm{a}}$ After $1 \mathrm{~h}$ the reaction mixture was treated with an aqueous solution of $\mathrm{NaHSO}_{4}(1 \mathrm{M})$. Then the organic layer was separated and the aqueous layer was extracted with $\mathrm{Et}_{2} \mathrm{O}(3 \times 2 \mathrm{~mL})$. The combined organic phases were washed with an aqueous saturated solution of $\mathrm{NaCl}$, dried over anhydrous $\mathrm{Na}_{2} \mathrm{SO}_{4}$ and the solvent was removed under reduced pressure after filtration. The crude product was purified by column chromatography $\left(\mathrm{SiO}_{2}\right.$, pentane/ $\left./ \mathrm{Et}_{2} \mathrm{O} \quad 8: 1 \rightarrow 1: 2\right)$ affording products 1a (3\%), 1a' $(6 \%), 13(8 \%)$ and 14 $(8 \%)$. The spectral and analytical data for 1a', 13 and 14 are as follows.

\section{2-(2-Acetyl-1-methylcyclopent-2-enyl)acetaldehyde} (1a')

Yellow oil.

IR $(\mathrm{KBr}$ film $)\left(\mathrm{cm}^{-1}\right) \vee 3440,2930,1708,1665,1365$, $1264,1102$.

${ }^{1} \mathrm{H}$ NMR $\left(500 \mathrm{MHz}, \mathrm{CDCl}_{3}\right): \delta 9.69(\mathrm{dd}, J=3.2,1.9$ $\mathrm{Hz}, 1 \mathrm{H}), 6.76(\mathrm{t}, J=2.8 \mathrm{~Hz}, 1 \mathrm{H}), 2.87$ (dd, $J=15.4$, $1.9 \mathrm{~Hz}, 1 \mathrm{H}), 2.70(\mathrm{dd}, J=15.5,3.1 \mathrm{~Hz}, 1 \mathrm{H}), 2.53-2.45$ (m, 2H), 2.30 (s, 3H), 1.99 (ddd, $J=13.0,8.6,7.4 \mathrm{~Hz}$, $1 \mathrm{H}), 1.83$ (ddd, $J=13.2,8.2,5.0 \mathrm{~Hz}, 1 \mathrm{H}), 1.30$ (s, $3 \mathrm{H})$.

${ }^{13} \mathrm{C}$ NMR $\left(125 \mathrm{MHz}, \mathrm{CDCl}_{3}\right): \delta 202.9,196.9,149.7$, 145.9, 52.6, 47.1, 38.2, 30.5, 27.7, 26.1.

GC-EI-MS m/z (\%) 122 (100), 138 (70), 151 (10), 166 (3) $[\mathrm{M}]^{+}$.

GC-EI-HRMS $\left([\mathrm{M}]^{+}\right)$calcd for $\mathrm{C}_{10} \mathrm{H}_{14} \mathrm{O}_{2}$ 166.0988, found 166.0986 .

\section{6-Hydroxy-7a-methyl-5,6,7,7a-tetrahydro-1H- inden-4(2H)-one (13)}

Yellow oil.

IR (KBr film) $\left(\mathrm{cm}^{-1}\right) \vee$ 3430, 2931, 1774, 1617, 1253 , $1151,1044$.

${ }^{1} \mathrm{H}$ NMR $\left(500 \mathrm{MHz}, \mathrm{CDCl}_{3}\right): \delta 6.51(\mathrm{t}, J=2.7 \mathrm{~Hz}$, $1 \mathrm{H}), 4.35-4.28(\mathrm{~m}, 1 \mathrm{H}), 2.87$ (ddd, $J=16.7,5.3,2.1$

$\mathrm{Hz}, 1 \mathrm{H}), 2.59-2.49(\mathrm{~m}, 1 \mathrm{H}), 2.47-2.38(\mathrm{~m}, 1 \mathrm{H}), 2.33-$ $2.20(\mathrm{~m}, 2 \mathrm{H}), 2.03-1.95(\mathrm{~m}, 1 \mathrm{H}), 1.92-1.84(\mathrm{~m}, 1 \mathrm{H})$, 1.64-1.60 (m, 2H), $1.08(\mathrm{~s}, 3 \mathrm{H})$.

${ }^{13} \mathrm{C}$ NMR $\left(125 \mathrm{MHz}, \mathrm{CDCl}_{3}\right): \delta$ 197.1, 148.0, 137.2, 66.6, 50.1, 47.6, 45.6, 42.4, 30.4, 25.1.

GC-EI-HRMS ([M] $]^{+}$calcd for $\mathrm{C}_{10} \mathrm{H}_{14} \mathrm{O}_{2}$ 166.0988, found 166.0993.

\section{7a-Methyl-7,7a-dihydro-1H-inden-4(2H)-one (14)}

Yellow oil.
IR (KBr film) $\left(\mathrm{cm}^{-1}\right) \vee$ 3447, 2960, 2926, 1688, 1455, 1382, 1261, 1098, 1024.

${ }^{1} \mathrm{H}$ NMR (400 MHz, $\left.\mathrm{CDCl}_{3}\right): \delta 6.89$ (ddd, $J=10.3$, $6.0,2.3 \mathrm{~Hz}, 1 \mathrm{H}), 6.65$ (t, $J=2.8 \mathrm{~Hz}, 1 \mathrm{H}), 6.12$ (ddd, $J$ $=10.0,3.0,1.0 \mathrm{~Hz}, 1 \mathrm{H}), 2.60-2.32(\mathrm{~m}, 4 \mathrm{H}), 2.05(\mathrm{ddd}$, $J=12.5,6.0,2.5 \mathrm{~Hz}, 1 \mathrm{H}), 1.88(\mathrm{dt}, J=12.5,9.5 \mathrm{~Hz}$, $1 \mathrm{H}), 1.12(\mathrm{~s}, 3 \mathrm{H})$.

${ }^{13} \mathrm{C}$ NMR $\left(125 \mathrm{MHz}, \mathrm{CDCl}_{3}\right): \delta 186.8,148.5,146.9$, 137.0, 130.5, 46.9, 41.5, 41.2, 30.3, 25.0.

ESI-MS m/z (\%) 149 (100) [M+1] .

GC-EI-HRMS ([M] $]^{+}$) calcd for $\mathrm{C}_{10} \mathrm{H}_{12} \mathrm{O}$ 148.0883, found 148.0875 .

Syntesis of (+)-Mitsugashiwalactone (17)

\section{(R)-4,4a,5,6-Tetrahydrocyclopenta[c]pyran-1(3H)-} one (19) ${ }^{52 \mathrm{a}, 59}$

$\mathrm{MnO}_{2}(1.75 \mathrm{~g}, 20.13 \mathrm{mmol})$ was added to a solution of diol 18 (159 mg, $1.12 \mathrm{mmol}, 43 \%$ ee (after derivatization $)^{57}$ in $\mathrm{CHCl}_{3}(5 \mathrm{~mL})$. The resulting mixture was stirred at $66^{\circ} \mathrm{C}$ for $12 \mathrm{~h}$, and then filtered. The solvent was removed under reduced pressure. The crude product was purified by column chromatography $\left(\mathrm{SiO}_{2}\right.$, pentane/EtOAc 3:1) to afford lactone $\mathbf{1 9}^{51 \mathrm{~b}}$ in $71 \%$ yield $(110 \mathrm{mg})$ as a light yellow oil.

$[\alpha]_{D^{22}}{ }^{22}=-12.1\left(c=1.00, \mathrm{CHCl}_{3}, 10 \%\right.$ ee $)\left\{\right.$ lit. $^{51 \mathrm{~b}}$ $[\alpha]_{\mathrm{D}}^{31}=-116.6\left(c=0.93, \mathrm{CHCl}_{3},>99 \%\right.$ ee $\left.\left.(\mathrm{HPLC})\right)\right\}$. IR ( $\mathrm{KBr}$ film) $\left(\mathrm{cm}^{-1}\right) \vee 1715,1628,1255,743$.

${ }^{1} \mathrm{H}$ NMR $\left(400 \mathrm{MHz}, \mathrm{CDCl}_{3}\right): \delta 6.99(\mathrm{~d}, J=2.5 \mathrm{~Hz}$, $1 \mathrm{H}), 4.45$ (ddd, $J=11.6,4.5,2.0 \mathrm{~Hz}, 1 \mathrm{H}), 4.31$ (dt, $J$ $=11.5,2.5 \mathrm{~Hz}, 1 \mathrm{H}), 2.97($ br s, $1 \mathrm{H}), 2.50-2.45(\mathrm{~m}$, $2 \mathrm{H}), 2.41-2.34(\mathrm{~m}, 1 \mathrm{H}), 2.10$ (br dt, $J=13.5,2.5 \mathrm{~Hz}$, 1H), $1.73-1.58$ (m, 2H).

${ }^{13} \mathrm{C}$ NMR $\left(100 \mathrm{MHz}, \mathrm{CDCl}_{3}\right): \delta 163.5,145.5,134.7$, 69.7, 42.0, 32.7, 31.7, 30.8 .

ESI-MS m/z (\%) 93 (27), 111 (33), 139 (100) [M+H] ${ }^{+}$. HPLC-EI-HRMS $\left([\mathrm{M}+\mathrm{H}]^{+}\right)$calcd for $\mathrm{C}_{8} \mathrm{H}_{11} \mathrm{O}_{2}$ 139.07536, found 139.07509 .

(4aR,7S,7aR)-7-

Methylhexahydrocyclopenta[c]pyran-1(3H)-one $(17)^{51 b}$

To a solution of lithium dimethylcuprate [prepared in situ by mixing $\mathrm{CuI}(310 \mathrm{mg}, 1.63 \mathrm{mmol})$ in $\mathrm{Et}_{2} \mathrm{O}$ $(2 \mathrm{~mL})$ and $\mathrm{MeLi}$ in $\mathrm{Et}_{2} \mathrm{O}(2.14 \mathrm{~mL}, 3.26 \mathrm{mmol}, 1.6 \mathrm{M}$ in $\left.\mathrm{Et}_{2} \mathrm{O}\right)$ at $-25^{\circ} \mathrm{C}$ ], lactone $19(75 \mathrm{mg}, 0.54 \mathrm{mmol})$ in $\mathrm{Et}_{2} \mathrm{O}(1 \mathrm{~mL})$ was added at $-25^{\circ} \mathrm{C}$ and stirring at the same temperature for $30 \mathrm{~min}$. Then a saturated aqueous solution of $\mathrm{NH}_{4} \mathrm{Cl}$ was added, and the mixture was extracted with $\mathrm{Et}_{2} \mathrm{O}(3 \times 7 \mathrm{~mL})$. The combined organic phases were washed with brine $(2 \mathrm{~mL})$, dried over anhydrous $\mathrm{MgSO}_{4}$ and the solvent was removed under reduced pressure after filtration. The crude product was purified by column chromatography $\left(\mathrm{SiO}_{2}\right.$, pentane/EtOAc 4:1) to afford (+) mitsugashiwalactone $(\mathbf{1 7})^{51}$ in $84 \%$ yield $(70 \mathrm{mg})$ as colorless oil. 
$[\alpha]_{\mathrm{D}}^{20}=+0.6\left(c=2.00, \mathrm{CHCl}_{3}\right)\left\{\right.$ lit. $^{51 \mathrm{~b}}[\alpha]_{\mathrm{D}}{ }^{32}=+5.3$ $\left(c=0.92, \mathrm{CHCl}_{3}\right),[\alpha]_{\mathrm{D}}^{32}=+6.3\left(c=0.96, \mathrm{CCl}_{4}\right)$, $[\alpha]_{\mathrm{D}}{ }^{24}=+4.6\left(c=2.00, \mathrm{CHCl}_{3}\right)$, natural ${ }^{51 \mathrm{a}}[\alpha]_{\mathrm{D}}{ }^{32}=$ +6.4 (not described) $\}$.

IR $(\mathrm{KBr}$ film $)\left(\mathrm{cm}^{-1}\right) \vee$ 3018, 2956, 2926, 2856, 1723, $1216,756$.

${ }^{1} \mathrm{H}$ NMR (400 MHz, $\left.\mathrm{CDCl}_{3}\right): \delta 4.33$ (ddd, $J=11.1$, $6.6,3.0 \mathrm{~Hz}, 1 \mathrm{H}), 4.20(\mathrm{ddd}, J=11.0,8.5,2.5 \mathrm{~Hz}, 1 \mathrm{H})$, 2.59-2.54 (m, 1H), $2.38(\mathrm{t}, J=9.6 \mathrm{~Hz}, 1 \mathrm{H}), 2.26-2.20$ $(\mathrm{m}, 1 \mathrm{H}), 2.04-2.00(\mathrm{~m}, 2 \mathrm{H}), 1.94-1.90(\mathrm{~m}, 1 \mathrm{H}), 1.57-$ $1.50(\mathrm{~m}, 1 \mathrm{H}), 1.33-1.18(\mathrm{~m}, 2 \mathrm{H}), 1.21(\mathrm{~d}, J=6.5 \mathrm{~Hz}$, $3 \mathrm{H})$.

${ }^{13} \mathrm{C}$ NMR $\left(100 \mathrm{MHz}, \mathrm{CDCl}_{3}\right): \delta 174.6,66.9,50.2$, 39.5, 36.2, 34.7, 32.7, 29.2, 19.9 .

ESI-MS m/z (\%) 109 (55), 155 (100) $[\mathrm{M}+\mathrm{H}]^{+}$.

HPLC-EI-HRMS $\left([\mathrm{M}+\mathrm{H}]^{+}\right)$calcd for $\mathrm{C}_{9} \mathrm{H}_{15} \mathrm{O}_{2}$ 155.10666, found 155.10635 .

\section{Organocatalytic Cyclization of 20 - Six Membered Rings}

Following the general procedure starting from 20a (114.90 $\mathrm{mg}, 0.04 \mathrm{mmol}$ ), after $48 \mathrm{~h}$ of reaction, products 21 a ( $9 \%$ yield, $76 \%$ ee) and 27 (12\% yield, $>99 \%$ ee) were obtained after column chromatography $\left(\mathrm{SiO}_{2}\right.$, pentane/Et $\left.{ }_{2} \mathrm{O} 4: 1 \rightarrow 2: 1\right) ;(21 \mathrm{a}: 27=24: 76$, by ${ }^{1} \mathrm{H}$ NMR of the crude product).

\section{2-Methyl-6-(2-(4-nitrophenyl)-2-oxoethyl)cyclohex- 1-enecarbaldehyde (21a)}

HPLC conditions: Daicel Chiralpak IA column (hexane/i-PrOH 90:10, flow rate $1.0 \mathrm{~mL} / \mathrm{min}, \mathrm{UV}$ $254.4 \mathrm{~nm}, \tau_{\text {major }}=20.4 \mathrm{~min} ; \tau_{\text {minor }}=24.2 \mathrm{~min}$ ).

${ }^{1} \mathrm{H}$ NMR (400 MHz, $\left.\mathrm{CDCl}_{3}\right): \delta 10.17(\mathrm{~s}, 1 \mathrm{H}), 8.39-$ $8.24(\mathrm{~m}, 4 \mathrm{H}), 3.36(\mathrm{dd}, J=14.6,3.0 \mathrm{~Hz}, 1 \mathrm{H}), 3.25-$ $3.20(\mathrm{~m}, 1 \mathrm{H}), 2.68(\mathrm{dd}, J=14.6,11.0 \mathrm{~Hz}, 1 \mathrm{H}), 2.31-$ $2.24(\mathrm{~m}, 2 \mathrm{H}), 2.20(\mathrm{~s}, 3 \mathrm{H}), 1.77-1.63(\mathrm{~m}, 3 \mathrm{H}), 1.56-$ $1.48(\mathrm{~m}, 1 \mathrm{H})$.

${ }^{13} \mathrm{C}$ NMR (125 MHz, $\left.\mathrm{CDCl}_{3}\right): \delta 198.5,191.0,159.1$, $150.5,141.2,136.0,129.8,124.0,43.2,34.5,28.7$, 25.6, 18.9, 17.4 .

EI-MS m/z (\%) 94 (100), 150 (80), 259 (85), 270 (50), 287 (10) $[\mathrm{M}]^{+}$.

GC-EI-HRMS ([M] $]^{+}$) calcd for $\mathrm{C}_{16} \mathrm{H}_{17} \mathrm{O}_{4} \mathrm{~N} 287.1152$, found 287.1151 .

\section{2-Methyl-6-(2-(4-nitrophenyl)-2-oxoethyl)cyclohex- 2-enecarbaldehyde (27)}

HPLC conditions: Daicel Chiralpak IB column (hexane/i-PrOH 80:20, flow rate $0.5 \mathrm{~mL} / \mathrm{min}$, UV $254.4 \mathrm{~nm}, \tau_{\text {major }}=20.6 \mathrm{~min}$; $\tau_{\text {minor }}=25.0 \mathrm{~min}$ ).

${ }^{1} \mathrm{H} \mathrm{NMR}\left(400 \mathrm{MHz}, \mathrm{CDCl}_{3}\right): \delta 9.58(\mathrm{~d}, J=2.9 \mathrm{~Hz}$, $1 \mathrm{H}), 8.32(\mathrm{~d}, J=8.8 \mathrm{~Hz}, 2 \mathrm{H}), 8.10(\mathrm{~d}, J=8.8 \mathrm{~Hz}$, 2H), 5.77 (br s, 1H), 3.09 (dd, $J=17.6,6.5 \mathrm{~Hz}, 1 \mathrm{H})$, 2.99 (dd, $J=17.6,6.5 \mathrm{~Hz}, 1 \mathrm{H}), 2.85-2.77(\mathrm{~m}, 1 \mathrm{H})$, 2.72 (br s, $1 \mathrm{H}), 2.13-2.07(\mathrm{~m}, 2 \mathrm{H}), 1.82-1.74(\mathrm{~m}, 1 \mathrm{H})$, 1.73 (br s, 3H), 1.50-1.37 (m, 1H).

EI-MS m/z (\%) 94 (100), 150 (80), 259 (85), 270 (40), 287 (10) $[\mathrm{M}]^{+}$.
GC-EI-HRMS $\left([\mathrm{M}]^{+}\right)$calcd for $\mathrm{C}_{16} \mathrm{H}_{17} \mathrm{O}_{4} \mathrm{~N}$ 287.1152, found 287.1150 .

\section{6-(2-(4-Chlorophenyl)-2-oxoethyl)-2- methylcyclohex-1-enecarbaldehyde (21b)}

Following the general procedure starting from 20b (52.4 mg, $0.19 \mathrm{mmol}), 21 \mathrm{~b}$ was obtained after $3 \mathrm{~d}$ in $7 \%$ yield $(3.51 \mathrm{mg})$ after column chromatography $\left(\mathrm{SiO}_{2}\right.$, pentane $\left./ \mathrm{Et}_{2} \mathrm{O} 6: 1\right), 82 \%$ ee.

HPLC conditions: Daicel Chiralpak IA column (hexane/i-PrOH 90:10, flow rate $0.5 \mathrm{~mL} / \mathrm{min}$, UV $254.4 \mathrm{~nm}, \tau_{\text {minor }}=19.6 \mathrm{~min}$; $\tau_{\text {major }}=22.8 \mathrm{~min}$ ).

${ }^{1} \mathrm{H}$ NMR (400 MHz, $\left.\mathrm{CDCl}_{3}\right): \delta 10.17(\mathrm{~s}, 1 \mathrm{H}), 8.08(\mathrm{~d}$, $J=8.5 \mathrm{~Hz}, 2 \mathrm{H}), 7.45(\mathrm{~d}, J=8.5 \mathrm{~Hz}, 2 \mathrm{H}), 3.30$ (dd, $J=$ $14.7,3.0 \mathrm{~Hz}, 1 \mathrm{H}), 3.25-3.20(\mathrm{~m}, 1 \mathrm{H}), 2.60(\mathrm{dd}, J=$ 14.7, $11.2 \mathrm{~Hz}, 1 \mathrm{H}), 2.27-2.24(\mathrm{~m}, 2 \mathrm{H}), 2.19$ (s, 3H), $1.79-1.53(\mathrm{~m}, 3 \mathrm{H}), 1.54-1.40(\mathrm{~m}, 1 \mathrm{H})$.

${ }^{13} \mathrm{C}$ NMR $\left(125 \mathrm{MHz}, \mathrm{CDCl}_{3}\right): \delta 198.9,191.0,158.6$, $139.5,136.4,135.2,130.2,129.0,42.6,34.5,28.8$, $25.5,18.8,17.4$.

HPLC-ESI-HRMS $\left([\mathrm{M}+\mathrm{H}]^{+}\right)$calcd for $\mathrm{C}_{16} \mathrm{H}_{18} \mathrm{O}_{2} \mathrm{Cl}$ 277.09898 , found 277.09917.

Supporting Information for this article is available online at http://www.thiemeconnect.com/ejournals/toc/synthesis.

\section{Acknowledgment}

We thank the Fonds der Chemischen Industrie for a Dozentenstipendium (M.C.), the DFG (Priority Program 1179 Organocatalysis), Spanish Government (CTQ2010-19606-C0201), the Humboldt Foundation (postdoctoral (E.M.-L.) and experienced researcher (R.P.H.) fellowships). Finally, we thank Dr. Pablo J. Sanz Miguel (TU-Dortmund) [X-ray], Dr. Wolf Hiller (TU-Dortmund) $\left[{ }^{2} \mathrm{H}\right.$ NMR], and Nina Mészéros (TUDortmund) [ESI-HRMS].

\section{References}

(1) New address for E. Marqués-López and R. P. Herrera.

(2) Asymmetric synthesis: More methods and applications; Christmann, M.; Bräse, S., Eds.; Wiley-VCH: Weinheim, 2012.

(3) For selected reviews on organocatalysis, see for example: (a) Dalko, P. I.; Moisan, L. Angew. Chem. Int. Ed. 2004, 43, 5138. (b) Asymmetric Organocatalysis; Berkessel, A.; Gröger, H., Eds.; Whiley-VHC: Weinheim, 2004. (c) Asymmetric organocatalysis in Acc. Chem. Res. 2004, 37 (8), 487; Houk, K. N.; List, B., Eds. (special issue on organocatalysis). (d) Seayed, J.; List, B. Org. Biomol. Chem. 2005, 3, 719. (e) Enantioselective oganocatalysis; Dalko, P. I., Ed.; Whiley-VCH: Weinheim, 2007. (f) Organocatalysis in Chem. Rev. 2007, 107 (12), 5413; List, B., Ed. (special issue on organocatalysis). (g) Dondoni, A.; Massi, A. Angew. Chem. Int. Ed. 2008, 47, 4638. (h) Asymmetric organocatalysis; Top Curr. Chem. 2010, 291, 1; List, B., Ed. (i) Fundamentals in organocatalysis. Past, present and future in Curr. Org. Chem. 2011, 15 (13), 2082; Herrera, R. P., Ed. (special issue on organocatalysis). (j) Buckley, B. R.; Kimber, M. C.; Slater, N. H. Annu. Rep. Prog. Chem., Sect. B: Org. Chem. 2012, 108, 98. (k) Science of synthesis, Asymmetric organocatalysis 1, Lewis base and acid catalysts; List, B., Ed.; Thieme: 
Stuttgart, 2012. (1) Science of synthesis, Asymmetric organocatalysis 1, Brønsted base and acid catalysts, and additional topics; Maruoka, K., Ed.; Thieme: Stuttgart, 2012. (m) Comprehensive enantioselective organocatalysis; Dalko, P. I., Ed.; Wiley-VCH, Weinheim, 2013.

(4) For applications of organocatalysis in the synthesis of natural products and non-natural biologically active molecules, see: (a) de Figueiredo, R. M.; Christmann, M. Eur. J. Org. Chem. 2007, 2575. (b) Marqués-López, E.; Herrera, R. P.; Christmann, M. Nat. Prod. Rep. 2010, 27, 1138. (c) Christmann, M. Applications of aminocatalysis in target-oriented synthesis in Science of synthesis, Asymmetric organocatalysis 1, Lewis base and acid catalysts; List, B., Ed.; Thieme: Stuttgart, 2012, 439. (d) Marqués-López, E.; Herrera, R. P. in Comprehensive enantioselective organocatalysis; Dalko, P. I., Ed.; Wiley-VCH, Weinheim, 2013.

(5) For reviews on aminocatalysis, see: (a) Palomo, C.; Mielgo, A. Angew. Chem. Int. Ed. 2006, 45, 7876. (b) Mielgo, A.; Palomo, C. Chem. Asian J. 2008, 3, 922. (c) Barbas III, C. F. Angew. Chem. Int. Ed. 2008, 47, 42. (d) Melchiorre, P.; Marigo, M.; Carlone, A.; Bartoli, G. Angew. Chem. Int. Ed. 2008, 47, 6138. (e) Bertelsen, S.; Jørgensen, K. A. Chem. Soc. Rev. 2009, 38, 2178. (f) List, B. Angew. Chem. Int. Ed. 2010, 49, 1730.

(6) For reviews about organocatalytic reactions catalyzed by chiral primary amines, see: (a) Peng, F.; Shao, Z. J. Mol. Catal. A, 2008, 285, 1. (b) Xu, L.-W.; Luo, J.; Lu, Y. Chem. Commun. 2009, 1807.

(7) For reviews, see: (a) Mukherjee, S.; Yang, J. W.; Hoffmann, S.; List, B. Chem. Rev. 2007, 107, 5471. (b) Phiko, P. M.; Majander, I.; Erkkilä, A. Top Curr. Chem. 2010, 291, 29.

(8) For reviews, see: Erkkilä, A.; Majander, I.; Phiko, P. M. Chem. Rev. 2007, 107, 5416. (b) Brazier, J. B.; Tomkinson, N. C. O. Top Curr. Chem. 2010, 291, 281.

(9) For reviews on $\alpha$-functionalization using enamine activation, see for example: (a) Marigo, M.; Jørgensen, K. A. Chem. Commun. 2006, 2001. (b) Guillena, G.; Ramón, D. J. Tetrahedron: Asymmetry 2006, 17, 1465.

(10) For reviews on conjugated additions using iminium-ion activation see, for example: (a) Tsogoeva, S. B. Eur. J. Org. Chem. 2007, 1701. (b) Almasi, D.; Alonso, D. A.; Nájera, C. Tetrahedron: Asymmetry 2007, 18, 299. (c) Vicario, J. L.; Badía, D.; Carrillo, L. Synthesis 2007, 2065.

(11) For recent reviews on dienamine catalysis, see: (a) Ramachary, D. B.; Reddy, Y. V. Eur. J. Org. Chem. 2012, 865. (b) Christmann, M. Asymmetric dienamine activation in Asymmetric synthesis: More methods and applications; Christmann, M.; Bräse, S. Eds.; WileyVCH: Weinheim, 2012, 43.

(12) For a recent review on trienamine catalysis, see: Kumar, I.; Ramaraju, P.; Mir, N. A. Org. Biomol. Chem. 2013, 11,709 , and references cited therein.

(13) For pioneering work, see: (a) Chen, S.-H.; Hong, B.-C.; Su, C.-F.; Sarshar, S. Tetrahedron Lett. 2005, 46, 8899. (b) Bertelsen, S.; Marigo, M.; Brandes, S.; Dinér, P.; Jørgensen, K. A. J. Am. Chem. Soc. 2006, 128, 12973. (c) Hong, B.-C.; Wu, M.-F.; Tseng, H.-C.; Liao, J.-H. Org. Lett. 2006, 8, 2217. (d) Bench, B. J.; Liu, C.; Evett, C. R.; Watanabe, C. M. H. J. Org. Chem. 2006, 71, 9458. (e) Utsumi, N.; Zhang, H.; Tanaka, F.; Barbas III, C. F. Angew. Chem. Int. Ed. 2007, 46, 1878.

(14) (a) Marqués-López, E.; Herrera, R. P.; Marks, T.; Jacobs, W. C.; Könning, D.; de Figueiredo, R. M.; Christmann, M. Org. Lett. 2009, 11, 4116. (b) Han, B.; Xiao, Y.-C.; He, Z.-Q.; Chen, Y.-C. Org. Lett. 2009, 11,
4660. (c) Han, B.; Xiao, Y.-C.; Yao, Y.; Chen, Y.-C. Angew. Chem. Int. Ed. 2010, 49, 10189.

(15) (a) Bencivenni, G.; Galzerano, P.; Mazzanti, A.; Bartoli, G.; Melchiorre, P. Proc. Natl. Acad. Sci. U.S.A. 2010, 107, 20642. (b) Bergonzini, G.; Vera, S.; Melchiorre, P. Angew. Chem. Int. Ed. 2010, 49, 9685. (c) Stiller, J.; Marqués-López, E.; Herrera, R. P.; Fröhlich, R.; Strohmann, C.; Christmann, M. Org. Lett. 2011, 13, 70. (d) Silvi, M.; Cassania, C.; Morana, A.; Melchiorre, P. Helv. Chim. Acta 2012, 95, 1985. (e) Bastida, D.; Liu, Y.; Tian, X.; Escudero-Adán, E.; Melchiorre, P. Org. Lett. 2013, 15, 220.

(16) For a recent example of organocascade reaction involving dienamine catalysis, see: Appayee, C.; Fraboni, A. J.; Brenner-Moyer, S. E. J. Org. Chem. 2012, 77, 8828

(17) (a) Hong, B.-C.; Tseng, H.-C.; Chen, S.-H. Tetrahedron 2007, 63, 2840. (b) Hong, B.-C.; Wu, M.-F.; Tseng, H.C.; Huang, G.-F.; Su, C.-F.; Liao, J.-H. J. Org. Chem. 2007, 72, 8459. (c) de Figueiredo, R. M.; Fröhlich, R.; Christmann, M. Angew. Chem. Int. Ed. 2008, 47, 1450. (d) Orue, A.; Reyes, E.; Vicario, J. L.; Carrillo, L.; Uria, U. Org. Lett. 2012, 14, 3740. (e) Feng, X.; Zhou, Z.; Zhou, R.; Zhou, Q.-Q.; Dong, L.; Chen, Y.-C. J. Am. Chem. Soc. 2012, 134, 19942.

(18) (a) Han, B.; He, Z.-Q.; Li, J.-L.; Li, R.; Jiang, K.; Liu, T.-Y.; Chen, Y.-C. Angew. Chem. Int. Ed. 2009, 48, 5474. For examples of inverse electron-demand Diels-Alder reactions, see: (b) Li, J.-L.; Kang, T.-R.; Zhou, S.-L.; Li, R.; Wu, L.; Chen, Y.-C. Angew. Chem. Int. Ed. 2010, 49, 6418. (c) Li, J.-L.; Zhou, S.-L.; Chen, P.-Q.; Dong, L.; Liu, T.-Y.; Chen, Y.-C. Chem. Sci. 2012, 3,1879 .

(19) For examples of asymmetric organocatalytic formal [2+2]-cycloadditions, see: (a) Albrecht, Ł.; Dickmeiss, G.; Cruz Acosta, F.; Rodríguez-Escrich, C.; Davis, R. L.; Jørgensen, K. A. J. Am. Chem. Soc. 2012, 134, 2543. (b) Talavera, G.; Reyes, E.; Vicario, J. L.; Carrillo, L. Angew. Chem. Int. Ed. 2012, 51, 4104.

(20) Rauhut, M. M.; Currier, H. US Patent 3,074,999, 1963.

(21) For a review on Rauhut-Currier reactions, see: Aroyan, C. E.; Dermenci, A.; Miller, S. J. Tetrahedron 2009, 65, 4069.

(22) For reviews on Morita-Baylis-Hillman reaction, see: (a) Masson, G.; Housseman, C.; Zhu, J. Angew. Chem. Int. Ed. 2007, 46, 4614. (b) Mansilla, J.; Saá, J. M. Molecules 2010, 15, 709. (c) Basavaiah, D.; Reddy, B. S.; Badsara, S. S. Chem. Rev. 2010, 110, 5447.

(23) Erguden, J. K.; Moore, H. W. Org. Lett. 1999, 1, 375.

(24) Wang, L.-C.; Luis, A. L.; Agapiou, K.; Jang, H.-Y.; Krische, M. J. J. Am. Chem. Soc. 2002, 124, 2402.

(25) (a) Frank, S. A.; Mergott, D. J.; Roush, W. R. J. Am. Chem. Soc. 2002, 124, 2404. (b) Thalji, R. K.; Roush, W. R. J. Am. Chem. Soc. 2005, 127, 16778.

(26) (a) Aroyan, C. E.; Miller, S. J. J. Am. Chem. Soc. 2007, 129, 256. (b) Aroyan, C. E.; Dermenci, A.; Miller, S. J. J. Org. Chem. 2010, 75, 5784. For an example of the application of the RC reaction in the synthesis of natural products, see: (c) Dermenci, A.; Selig, P. S.; Domaoal, R. A.; Spasov, K. A.; Anderson, K. S.; Miller, S. J. Chem. Sci. 2011, 2, 1568.

(27) Gong, J.-J.; Li, T.-Z.; Pan, K.; Wu, X.-Y. Chem. Commun. 2011, 47, 1491.

(28) Wang, X-F.; Peng, L.; An, J.; Li, C.; Yang, Q.-Q.; Lu, L.-Q.; Gu, F.-L.; Xiao, W.-J. Chem. Eur. J. 2011, 17, 6484.

(29) (a) Takizawa, S.; Nguyen, T. M.-N.; Grossmann, A.; Enders, D.; Sasai, H. Angew. Chem. Int. Ed. 2012, 51, 5423. (b) Takizawa, S.; Nguyen, T. M.-N.; Grossmann, 
A.; Suzuki, M.; Enders, D.; Sasai, H. Tetrahedron 2013 69, 1202.

(30) Zhang, X.-N.; Shi, M. Eur. J. Org. Chem. 2012, 6271.

(31) Jin, Z.; Yang, R.; Du, Y.; Tiwari, B.; Ganguly, R.; Chi, Y. R. Org. Lett. 2012, 14, 3226.

(32) For a non-organocatalyzed example, see: Seidel, F.; Gladysz, J. A. Synlett 2007, 986.

(33) For other examples of intramolecular non-chiral RC reaction, see: (a) Selig, P. S.; Miller, S. J. Tetrahedron Lett. 2011, 52, 2148. (b) MacKay, J. A.; Landis, Z. C.; Motika, S. E.; Kench, M. H. J. Org. Chem. 2012, 77, 7768.

(34) (a) Zhong, C.; Chen, Y.; Petersen, J. L.; Akhmedov, N G.; Shi, X. Angew. Chem. Int. Ed. 2009, 48, 1279. (b) Zhao, Q.-Y.; Pei, C.-K.; Guan, X.-Y.; Shi, M. Adv. Synth. Cat. 2011, 353, 1973. (c) Atienza, R. L.; Scheidt, K. A. Aust. J. Chem. 2011, 64, 1158. For an example of aza-Rauhut-Currier reactions, see: (d) Shi, Z.; Yu, P.; Loh, T.-P.; Zhong, G. Angew. Chem. Int. Ed. 2012, 51, 7825.

(35) For selected examples of non-enantioselective intermolecular RC reaction, see: (a) Reynolds, T. E.;

Binkley, M. S.; Scheidt, K. A. Org. Lett. 2008, 10, 2449. (b) Yao, W.; Wu, Y.; Wang, G.; Zhang, Y.; Ma, C. Angew. Chem. Int. Ed. 2009, 48, 9713. (c) Shanbhag, P.; Nareddy, P. R.; Dadwal, M.; Mobin, M. S.;

Namboothiri, I. N. N. Org. Biomol. Chem. 2010, 8 , 4867. For examples of non-enantioselective RC domino reactions, see: (d) Xie, P.; Huang, Y.; Lai, W.; Meng, X.; Chen, R. Org. Biomol. Chem. 2011, 9, 6707. (e) Ma, J.; Xie, P.; Hu, C.; Huang, Y.; Chen, R. Chem. Eur. J. 2011, 17, 7418. (f) Liu, W.; Zhou, J.; Zheng, C.; Chen, X.; Xiao, H.; Yang, Y.; Guo, Y.; Zhao, G. Tetrahedron 2011, 67, 1768. (g) Hu, C.; Geng, Z.; Ma, J.; Huang, Y.; Chen, R. Chem. Asian J. 2012, 7, 2032. For an example of aza-Rauhut-Currier, see: (h) Shi, Z.; Tong, Q.; Wen W.; Leong, Y.; Zhong, G. Chem. Eur. J. 2012, 18, 9802.

(36) For reviews on cyclopentenes, see: (a) Hudlicky, T.; Price, J. D. Chem. Rev. 1989, 89, 1467. (b) Hartley, R. C.; Caldwell, S. T. J. Chem. Soc. Perkin Trans. 1 2000, 477. (c) Heasley, B. Eur. J. Org. Chem. 2009, 1477.

(37) Tundis, R.; Loizzo, M. R.; Menichini, F.; Statti, G. A.; Menichini, F. Mini-Rev. Med. Chem. 2008, 8, 399.

(38) Boros, C. A.; Stermitz, F. R. J. Nat. Prod. 1990, 53, 1055.

(39) (a) Tietze, L.-F. Angew. Chem. Int. Ed. Engl. 1983, 22, 828. (b) Villasenor, I. M. Antiinflamm. Antiallergy Agents Med. Chem. 2007, 6, 307.

(40) Kim, H. J.; Ruszczycky, M. W.; Choi, S.-h.; Liu, Y.-n.; Liu, H.-w. Nature 2011, 473, 109.

(41) (a) Lorenz, M.; Boland, W.; Dettner, K. Angew. Chem. Int. Ed. Engl. 1993, 32, 912. (b) Weibel, D. B.; Oldham, N. J.; Feld, B.; Glombitza, G.; Dettner, K.; Boland, W. Insect Biochem. Mol. Biol. 2001, 31, 583. (c) Kunert, M.; Rahfeld, P.; Shaker, K. H.; Schneider, B.; David, A.; Dettner, K.; Pasteels, J. M.; Boland, W. ChemBioChem 2013. DOI: $10.1002 /$ cbic. 201200689.

(42) For references of the effect of Brønsted acids in MoritaBaylis-Hillman reaction, see: (a) Shi, M.; Liu, Y. Org. Biomol. Chem. 2006, 4, 1468. (b) Abermil, N.; Masson, G.; Zhu, J. J. Am. Chem. Soc. 2008, 130, 12596. (c) Yukawa, T.; Seelig, B.; Xu, Y.; Morimoto, H.; Matsunaga, S.; Berkessel, A.; Shibasaki, M. J. Am. Chem. Soc. 2010, 132, 11988.

(43) Watanabe, K.; Takada, Y.; Matsuo, N.; Nishimura, H. Biosci. Biotech. Biochem. 1996, 59, 1979.

(44) For the first total synthesis of $(R)$ - and $(S)$-rotundial, see: Takikawa, H.; Yamazaki, Y.; Mori, K. Eur. J. Org. Chem. 1998, 229.
(45) See Experimental Section.

(46) (a) Seebach, D.; Grošelj, U.; Badine, D. M.; Schweizer, W. B.; Beck, A. K. Helv. Chim. Acta 2008, 91, 1999. (b) Grošelj, U.; Schweizer, W. B.; Ebert, M.-O.; Seebach, D. Helv. Chim. Acta 2009, 92, 1.

(47) For theoretical discussions concerning dienamine intermediates, see: Duarte, F. J. S.; Cabrita, E. J.; Frenking, G.; Santos, A. G. Chem. Eur. J. 2009, 15, 1734.

(48) E/Z-Isomerization of the enol moiety of 5 could lead to an intramolecular attack of the iminium ion and to a dead end in the catalytic cycle.

(49) Preparation of the ESI-HRMS sample: After 5 minutes of reaction $20 \mu \mathrm{L}$ of the reaction mixture were taken, and the solvent was evaporated. The residue was solved in $\mathrm{CH}_{3} \mathrm{CN}(1 \mathrm{~mL})$.

(50) Schmid, M. B.; Zeitler, K.; Gschwind, R. M. Angew. Chem. Int. Ed. 2010, 49, 4997.

(51) (a) Weinges, K.; Ziegler, H. J.; Maurer, W.; Schmidbauer, S. B. Liebigs Ann. Chem. 1993, 1029. (b) Yamane, T.; Takahashi, M.; Ogasawara, K. Synthesis 1995, 444.

(52) (a) Amri, H.; Villieras, J. Tetrahedon Lett. 1987, 28, 5521. (b) Bouyssi, D.; Monteire, N.; Balme, G. Tetrahedron Lett. 1999, 40, 1297.

(53) Ohta, H.; Kobori, T.; Fujisawa, T. J. Org. Chem. 1977, 42, 1231.

(54) Wilson, R. M.; Jen, W. S.; MacMillan, D. W. C. J. Am. Chem. Soc. 2005, 127, 11616.

(55) X ray crystallographic analysis data for 27. CCDC 813588 contains the supplementary crystallographic data for this paper. These data can be obtained free of charge from the Cambridge Crystallographic Data Centre via www.ccdc.cam.ac.uk/data_request/cif.

(56) The absolute configuration for compounds 21a-b and 27 was not assigned unambiguously.

(57) For more details see Supporting Information.

(58) The synthesis of the products as racemic mixtures were carried out using a mixture of both enantiomers of the catalyst [(S)-IV:(R)-IV) $1: 1]$.

(59) (a) Amri, H.; Rambaud, M.; Villieras, J. Tetrahedron 1990, 46, 3535. (b) Nagata, H.; Ogasawara, K Tetrahedron Lett. 1999, 40, 6617. 